Discussion Paper No. 05-15

Rent-sharing: Does the Bargaining Regime Make a Difference?

Theory and Empirical Evidence

Nicole Gürtzgen

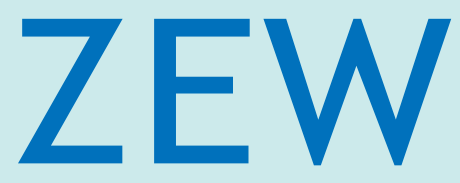

Zentrum für Europäische Wirtschaftsforschung $\mathrm{GmbH}$

Centre for European

Economic Research 
Discussion Paper No. 05-15

\title{
Rent-sharing: Does the Bargaining Regime Make a Difference? Theory and Empirical Evidence
}

\author{
Nicole Gürtzgen
}

Download this ZEW Discussion Paper from our ftp server:

\author{
ftp://ftp.zew.de/pub/zew-docs/dp/dp0515.pdf
}

Die Discussion Papers dienen einer möglichst schnellen Verbreitung von neueren Forschungsarbeiten des ZEW. Die Beiträge liegen in alleiniger Verantwortung der Autoren und stellen nicht notwendigerweise die Meinung des ZEW dar.

Discussion Papers are intended to make results of ZEW research promptly available to other economists in order to encourage discussion and suggestions for revisions. The authors are solely responsible for the contents which do not necessarily represent the opinion of the ZEW. 
Non-technical summary: This paper analyses whether wages in Germany respond to firm-specific profitability conditions. Particular emphasis lies on the question of whether the extent of rent-sharing varies across different systems of wage determination. Those may be categorised into sector-specific wage agreements, firm-specific wage agreements and wage determination without any bargaining coverage. To derive testable hypotheses, we set up a brief theoretical model that analyses the sensitivity of wages to firm-specific conditions under different wage setting structures. The main result is that the degree of rent-sharing is likely to be the larger the more coordinated the wage-setting process and the more decentralised the level of wage determination. We therefore expect wages to react stronger to local profitability conditions in firms that are covered by a collective contract and where wages are determined at the firm-level than in non-covered firms. Firm-level wage determination in covered firms may either occur under firm-specific contracts or under centralised contracts with the adoption of opening or hardship clauses.

The empirical analysis uses an establishment-level panel data set. The results generally suggest that rent-sharing is present in Germany. However, the extent of rent-sharing is found to be significantly lower in establishments that are subject to a collective wage agreement - irrespective of whether the agreement is industry- or firm-specific. While pooled OLS estimates yield positive estimates of the rent-sharing coefficient in establishments that are covered by a collective contract, SYS-GMMestimates accounting for unobserved heterogeneity and endogeneity of rents point to a rent-sharing coefficient of zero. For centralised wage-agreements, the invariance of wages against firm-specific profitability suggests that the use of flexibility provisions in central wage agreements appears to be empirically negligible. Even though firms may pay wages above the going rate and may make use of opting-out clauses, this potential for adjustments to local conditions at the firm-level appears to be largely unused. Even more surprising, however, is the invariance of wages against firm-profits in firms subject to a firm-specific wage contract. This result stands in sharp contrast to our theoretical analysis suggesting that under firm-specific contracts the sensitivity of wages to profits ought to be even larger than in non-covered firms. As firm-specific contracts are generally concluded by sector-specific unions, one possible explanation might be that a considerable fraction of firm-specific contracts simply adopts wage bargains negotiated in the corresponding sector agreement. 


\title{
Rent-sharing: Does the bargaining regime make a difference? Theory and empirical evidence
}

\author{
Nicole Guertzgen \\ Centre for European Economic Research, Mannheim* \\ February 2005
}

\begin{abstract}
This paper analyses whether wages in Germany respond to firm-specific profitability conditions. Particular emphasis lies on the question of whether the extent of rent-sharing varies across different systems of wage determination. Those may be categorised into sector-specific wage agreements, firm-specific wage agreements and wage determination without any bargaining coverage. To derive testable hypotheses, we set up a theoretical model that analyses the sensitivity of wages to firm-specific conditions under different wage setting structures. The hypotheses are tested using an establishment-level panel data set from the mining and manufacturing sector. The results of the empirical analysis generally suggest that rent-sharing is present in Germany. However, the extent of rent-sharing is found to be significantly lower in establishments that are subject to a collective wage agreement - irrespective of whether the agreement is industry- or firm-specific. While pooled OLS estimates yield positive estimates of the rent-sharing coefficient in establishments that are covered by a collective contract, SYS-GMM-estimates accounting for unobserved heterogeneity and endogeneity of rents point to a rent-sharing coefficient of zero.

Keywords: Rent-Sharing, Wage-Setting Structure, Unions, Panel Data

JEL Code: J31, J51, C23
\end{abstract}

\footnotetext{
*Centre for European Economic Research, Department of Labour Markets, Human Resources and Social Policy, L 7.1, 68161 Mannheim, Germany, E-Mail: Guertzgen@zew.de. I would like to thank Friedhelm Pfeiffer and Thomas Zwick for useful comments and discussions. I am particularly thankful to Dana Müller for data processing at the Research Data Centre (FDZ) of the Federal Employment Services (BA) at the Institute for Employment Research (IAB), Nuremberg. The institutions mentioned are not responsible for the use of the data in this publication. Financial support from the German Science Foundation (DFG) under the Program "Potentials for flexibility in heterogeneous labour markets" (Grant-No. PF 331/3-1) is gratefully acknowledged.
} 


\section{Introduction}

This paper deals with wage determination in Germany and addresses two major questions: first, do wages respond to firm-specific profitability conditions and second, does the extent of rent-sharing depend on the collective bargaining structure?

In the literature, various theoretical explanations have been advanced for a positive relationship between wages and profits (see e.g. Blanchflower et al. 1996, Hildreth and Oswald 1997). Apart from temporary frictions and efficiency wages, a frequently invoked explanation refers to union power. If wages are determined by collective bargaining, wages may be expected to increase with profits, as unions will be able to appropriate part of the industry- or firm-specific rents. Whether wages react to industry- and/or to firm-specific conditions crucially depends on the level of wage bargaining: wages ought to be most responsive to firm-specific profitability conditions if wage determination allows for some adjustment to local conditions at the firm level.

Although the bargaining structure appears to be an important determinant for the degree of rent-sharing at the firm- or industry-level, there is surprisingly little empirical evidence on this topic. While the question of whether wages vary systematically with firms' ability-to-pay has spawned a vast empirical literature ${ }^{1}$, few studies explicitly address the role of the bargaining structure for rent-sharing. One exception is the study of Holmlund and Zetterberg (1991), who analyse this question in a cross-country study. Our paper adds to the literature on rent-sharing, and we exploit intra-national variations in the bargaining structure. Clearly, such variations offer the advantage of controlling for a large part of the unobserved heterogeneity in institutional conditions characterising cross-country comparisons. ${ }^{2}$

The German case provides a useful example for the coexistence of different bargaining structures. Until the early 1990s, wage determination was dominated by centralised wage bargaining between industry-specific unions and employers' associations. Those industry agreements were embedded in a corporatist environment characterised by a high degree of coordination (Soskice 1990). However, in the last decade, there has been a strong tendency towards decentralisation of wage determination, since firm-specific collective wage agreements as well as wage determination

${ }^{1}$ The study of Blanchflower et al. (1996) is based on worker data matched to industryspecific profitability measures, whereas Christofides and Oswald (1992) and Abowd and Lemieux (1993) use collective contract data. Firm-level data are used by van Reenen (1996), Hildreth and Oswald (1997) and Dobbelaere (2004) among others. Finally, Abowd et al. (1999), Margolis and Salvanes (2001) as well as Arai (2003) provide examples for studies analysing matched worker-firm data. There are only few previous studies on the relationship between wages and profits in Germany: Hübler and König (1998) and Klodt (2000) use data from the 'Hannover establishment panel' and report a significant positive impact of profits on average firm wages.

2 There are number of studies which use intra-national variations in bargaining regimes to analyse the impact of the bargaining structure on the wage level and on the returns to worker attributes. See e.g. Hartog et al. (2002) and Cardoso and Portugal (2003). 
without any bargaining coverage have become more and more important (Hassel 1999, Ochel 2003). Even within centralised industry agreements, there have been numerous attempts to allow for more (downward) flexibility of wages by introducing opening and hardship clauses. Moreover, since bargained wages in centralised agreements merely represent a lower bound for wages, there is also sufficient room for upward flexibility.

Given this intra-national variation in German wage determination regimes, the principal aim of this paper is to shed light on the following questions: Do firmspecific contracts and flexibility provisions in centralised industry agreements allow for rent-sharing at the firm level? If yes, does the extent of rent-sharing differ from that in firms without any bargaining coverage? Thus far, the theoretical literature has mainly focused on the effects of different bargaining regimes on the overall wage level (see e.g. Calmfors and Driffill 1988, Soskice 1990, Dowrick 1993, Fitzenberger and Franz 1999). There is little theory to guide us on the expected effects on the returns to firm-specific attributes such as profits. To derive testable hypotheses for our empirical analysis, we set up a brief theoretical model that analyses the sensitivity of wages to firm-specific profitability conditions under different wage-setting structures. As is common in the literature (Calmfors and Driffill 1988, Soskice 1990), we distinguish between the level of wage determination and the degree of coordination. This distinction is particularly relevant for Germany, where decentralisation in collective wage determination merely refers to the level of bargaining and not to the degree of coordination. The reason is that - as will be discussed below - collective wage determination at the firm-level is generally influenced by industry-wide unions which may retain control over centralised union objectives. The main result of our analysis will be that the extent of rent-sharing is likely to be the larger the more coordinated the wage-setting process and the more decentralised the level of wage determination. Thus, shifting the bargaining locus to the firm level without changing the degree of coordination might enable unions to skim off an even larger part of rents as compared to a completely uncoordinated regime. The question of whether this theoretical result may be confirmed empirically is of considerable interest in an institutional environment such as the German one, which has long been pointed out as corporatist with little scope for excessive rent-sharing at the firm level.

In the empirical analysis, we investigate the relationship between wages and profitability using an establishment-level panel data set, the IAB-Establishment Panel. This data set is particularly useful for our purposes as it provides detailed information on whether an establishment is subject to an industry-wide wage agreement, a firmspecific wage agreement or to no wage agreement at all. In our estimation strategy, we first focus on simple static pooled Ordinary Least Squares (POLS) estimates, without taking into account the endogeneity of rents and unobserved firm-specific effects. The OLS estimations serve as a benchmark case and will be modified by applying dynamic panel data methods. First, we will address the possibility of unobserved firm-specific time invariant factors. A second problem concerns the endogeneity of our profitability measure, since wages and profits are simultaneously determined. As higher wages will reduce profits, OLS estimates will understate the true effect of profits on wages. 
Third, we will consider more dynamic specifications to allow for possible dynamics in the response of wages to profitability conditions.

The remainder of the paper is organised as follows: the institutional background of German wage determination is presented in Section 2. Section 3 sets up a theoretical model analysing whether the sensitivity of wages to firm-specific profitability conditions varies across different wage-setting regimes. From this we derive testable hypotheses for the empirical part of the paper, which follows in Section 4. While Section 4.1. presents the general empirical model, Section 4.2. describes the data set and the main variables used in the empirical analysis. Section 4.3. reports the estimation results. Finally, Section 5 provides a discussion and some conclusions.

\section{Institutional Background}

In Germany, basically three forms of wage determination may be distinguished: central collective wage agreements, firm-specific collective wage agreements as well as wage determination without any collective bargaining coverage. Until the early 1990s, wage determination was dominated by central regional and industry-wide collective wage agreements (Flächentarifverträge). Such central wage agreements are negotiated between an industry-specific trade union and an employers' association. They are legally binding for all firms being member of the respective employers' association and for all employees who are members of the trade union. Although the negotiated wage applies strictly speaking only to union members, member firms generally extend the wage settlement to non-member employees as well. The reason is that non-unionised employees who would receive a lower wage may be expected to join the union anyway in order to benefit from the higher union wage. Moreover, central wage agreements may also apply to non-member firms and their employees if the agreement is declared to be generally binding by the Federal Ministry of Labour.

Since the early 1990s, the German system of wage determination has experienced a considerable decline in the importance of centralised collective wage agreements (see e.g. Hassel 1999, Kohaut and Schnabel 2003). Instead, more decentralised forms of wage determination have gained in importance. This tendency towards decentralisation is caused by three major developments. First, firm-specific collective wage agreements have become more frequent. Those agreements are negotiated between an individual firm and the trade union. A noteworthy feature of those agreements is that they are concluded by sector-specific trade unions and do not involve uncoordinated wage bargaining of independent firm-specific unions. That is, decentralisation here merely refers to the level of bargaining and not to the degree of coordination. This distinguishes German firm-specific collective wage agreements from similar wage agreements in other countries, as e.g. in the U.K., where firm-specific unions bargain independently from each other (see e.g. OECD 2004). Second, wage determination without any bargaining coverage is becoming more relevant. In firms not being covered by an collective agreement wage determination may either take the form of individual wage contracts or of plant-specific agreements (Betriebsvereinbarungen) 
between works councils and the management. ${ }^{3}$ In contrast to firm-specific collective wage agreements, this kind of wage determination may be characterised as decentralised and uncoordinated. Third, there is a tendency even within centralised wage agreements to allow for more flexibility at the firm-level. In recent years, contractual opting-out clauses or hardship clauses have become a widespread element of central agreements. While opening clauses delegate issues that are usually specified in the central agreement, such as working-time and pay-conditions, to the plantlevel, hardship clauses enable firms to be exempted from the centralised agreement if they are close to bankruptcy. In general, the adoption of such clauses requires the approval of the collective bargaining parties (Hassel 1999, Ochel 2003). Thus, similar to firm-specific collective contracts, the adoption of flexibility provisions in central wage agreements is still coordinated by the centralised bargaining parties and involves merely a decentralisation of the level of bargaining.

To sum up, recent decentralisation tendencies in Germany have introduced - at least formally - the possibility to adjust wages to local conditions at the firm level. However, at this point it is worthy to note that the question of whether this potential has really been exploited still remains to be answered empirically. For example, even though contractual opening and hardship clauses have become an important (formal) element of centralised agreements, empirical evidence on the use of such clauses is rather sparse. ${ }^{4}$

\section{Theoretical Framework}

The purpose of the present section is guide the empirical analysis by deriving hypotheses about the degree of rent-sharing under the different wage determination regimes. In order to investigate the impact of collective bargaining coverage on the relationship between firm-specific profitability and wages, we employ a unionised oligopoly framework with different wage-setting structures similar to Haucap and Wey (2004). The wage-setting structures and their empirical counterparts are illustrated in Table 1.

To mirror the institutional variety in German bargaining institutions, we contrast a decentralised wage-setting structure (regime $(D)$ ), with wages being determined non-cooperatively at the firm level, with an intermediate and completely centralised structure with one encompassing industry union. While in the completely centralised case (regime $(C)$ ) an industry union sets one uniform wage for the entire industry, the intermediate centralised structure (regime $(I)$ ) allows for some adjustment to local conditions at the firm level. While regime $(C)$ is assumed to represent a central wage agreement without any adoption of hardship or opening clauses, regime $(I)$ is sup-

\footnotetext{
${ }^{3}$ According to the German Works Constitution Act, works councils are not allowed to negotiate about issues that are normally dealt with in collective agreements, even in firms that are not parties of a collective agreement. In practice, however, works councils may be expected to play a crucial role in wage determination (see e.g. Hassel 1999, Hübler and Jirjahn 2003).

${ }^{4}$ One exception is the study of Franz and Pfeiffer (2003), who analyse this issue based on an employer-survey.
} 
Abbr. Wage-setting structure

Empirical counterpart

\begin{tabular}{lll}
\hline \hline$(D)$ & $\begin{array}{l}\text { Decentralised and uncoordinated } \\
\text { Decentralised and coordinated } \\
\text { (Intermediate centralised) }\end{array}$ & $\begin{array}{l}\text { No bargaining coverage } \\
\text { Firm-specific collective agreement and } \\
\text { industry-wide collective agreement under } \\
\text { the adoption of flexibility provisions }\end{array}$ \\
& Centralised and coordinated & $\begin{array}{l}\text { Industry-wide collective agreement without } \\
\text { the adoption of flexibility provisions }\end{array}$ \\
\hline \hline
\end{tabular}

Table 1: Wage setting structures

posed to match firm-specific collective contracts as well as a central agreement with the adoption of flexibility provisions since it reflects the coordinated nature and the decentralised level of wage determination. ${ }^{5}$ Finally, regime $(D)$ is assumed to represent the wage determination process in firms without collective bargaining coverage. Although we are aware of the fact that regime $(D)$ assuming uncoordinated union wage-setting does not exactly match the institutional conditions in firms without any bargaining coverage, we consider it here as a benchmark scenario for the following two reasons. First, it reflects the uncoordinated nature of wage determination in firms without any bargaining coverage. Second, at least in codetermined firms a collective wage determination framework appears to be appropriate since empirical evidence suggests that German works councils affect wage outcomes even in firms that are not covered by a collective wage contract (Hübler and Jirjahn 2003).

\subsection{The Model}

The modelling framework is borrowed from Haucap and Wey (2004). We extend their duopoly model to an $n$-firm oligopoly to derive as general conclusions as possible. In contrast to the majority of the rent-sharing literature, whose theoretical predictions are based on structural equations derived from an efficient bargaining model where wages as well as employment are bargained over (see e.g. Blanchflower 1996, van Reenen 1996, Hildreth and Oswald 1997), we assume a right-to-manage framework where unions set wages ${ }^{6}$ and firms unilaterally decide on the employment level. In order to investigate to which extent rent-sharing differs across the different wage determination regimes, we analyse and compare the magnitudes of wage responses to firm-specific profitability conditions across the three regimes. Differences in firmspecific profitabilities within each wage-setting regime are introduced by imposing heterogeneous labour productivities of otherwise homogeneous labour.

Consider a homogeneous Cournot oligopoly with $n$ firms each producing output $q_{i}, i=1, \ldots, n$. Product demand is assumed to be linear with

\footnotetext{
${ }^{5}$ Unfortunately, in the empirical analysis, direct information on the use of flexibility provisions in firms subject to a centralised wage agreement is unavailable in our data. Whether centralised agreements correspond to regime $(I)$ or rather to regime $(C)$, therefore has to be tested empirically. In this regard, we will interpret our empirical findings as an indirect test of whether the use of flexibility provisions in central wage agreements is a quantitatively important phenomenon in Germany.

${ }^{6}$ This amounts to the assumption that unions have the whole bargaining power.
} 


$$
P=a-b \sum_{i=1}^{n} q_{i}
$$

where $P$ is the homogeneous good price. Firms produce with a constant marginal product of homogeneous labour, the only variable factor of production. To generate heterogeneity in firms' profitability conditions, suppose that each firm $i$ requires $c_{i}$ units of labour to produce a unit of the homogeneous good, so that labour demand $l_{i}$ equals $c_{i} q_{i}$. With $w_{i}$ denoting the wage each firm $i$ has to pay for one unit of labour, marginal costs are therefore $c_{i} w_{i}$. Firms' profit functions take the form

$$
\pi_{i}=\left(a-b \sum_{j=1}^{n} q_{j}\right) q_{i}-q_{i} c_{i} w_{i}, \quad i=1, \ldots, n .
$$

Maximising each firm's profit function for given wages $w_{i}$ and given $c_{i}$ with respect to $q_{i}$, taking $q_{j}, j \neq i$, as given yields equilibrium quantities

$$
q_{i}=\frac{a-n c_{i} w_{i}+\sum_{j \neq i} c_{j} w_{j}}{b(n+1)}, i=1, \ldots, n .
$$

Industry output $Q$ is given by

$$
Q=\frac{n a-n \sum_{i=1}^{n} c_{i} w_{i}+(n-1) \sum_{i=1}^{n} c_{i} w_{i}}{b(n+1)}=\frac{n a-\sum_{i=1}^{n} c_{i} w_{i}}{b(n+1)} .
$$

A right-to-manage framework results in a two-stage game structure, with unions setting optimal wages in the first stage of the game while anticipating the Cournot equilibrium quantities from the second stage of the game. Distinguishing three wagesetting regimes as outlined above gives rise to the following union wage-setting games:

1. Decentralisation $(D)$ : Completely decentralised wage-setting takes place with $n$ firm-unions each setting its optimal (firm-specific) wage independently from the other $(n-1)$ unions, taking their wages as given.

2. Complete centralisation $(C)$ : Centralised wage-setting takes place with one industry-wide union representing the interests of all workers in the industry and setting a uniform wage for all $n$ firms.

3. Intermediate centralisation $(I)$ : Under intermediate centralised wage-setting one industry-wide union settles for firm-specific wages while coordinating the wage demands in all firms of the industry.

As regards union preferences, unions are assumed to maximise the wage bill. Equilibrium wages are therefore solutions of the following programs

$$
w_{i}=\arg \max _{w_{i}} U_{i}^{r}\left(w_{1}, \ldots, w_{n}\right) \quad \text { s.t. eq. (3), }
$$

with $r=D, I, C$. More specifically, for the different union structures we have 


$$
\begin{gathered}
U_{i}^{D}\left(w_{1}, \ldots, w_{n}\right)=\left(w_{i}-\bar{w}\right) l_{i}, i=1, \ldots, n, \\
U^{I}\left(w_{1}, \ldots, w_{n}\right)=\sum_{j=1}^{n}\left(w_{j}-\bar{w}\right) l_{j},
\end{gathered}
$$

and

$$
U^{C}\left(w_{1}, \ldots, w_{n}\right)=\sum_{j=1}^{n}(w-\bar{w}) l_{j},
$$

with $\bar{w}$ denoting the alternative wage level, which workers may expect to earn elsewhere in the economy. This gives rise to $n$ first-order conditions in the decentralised and intermediate centralised regime $(D)$ and $(I)$ and to one first-order condition in the completely centralised case $(C) .{ }^{7}$

\subsection{Theoretical Results}

Proposition 1 Under the three wage-setting structures we obtain the following equilibrium wage outcomes:

(i)

$$
w_{i}^{D}=\frac{(2 n+1) a / c_{i}+n \bar{w}\left[(n+1)+n\left(\bar{c} / c_{i}\right)\right]}{(n+1)(2 n+1)}, i=1, \ldots, n,
$$

(ii)

$$
w_{i}^{I}=\frac{\bar{w}}{2}+\frac{a}{2 c_{i}}, i=1, \ldots, n
$$

(iii)

$$
w^{C}=\frac{\bar{w}}{2}+\frac{a}{2[(n+1) V A R(c) / \bar{c}+\bar{c}]}
$$

where $\bar{c}=\frac{1}{n} \sum_{j=1}^{n} c_{j}$ denotes the average labour-input-coefficient, that is the average inverse labour productivity in the industry and $V A R(c)=\frac{1}{n} \sum_{j=1}^{n}\left(c_{j}-\bar{c}\right)^{2}$ represents a measure of industry-wide dispersion of $c_{i}$.

Proof. See the Appendix.

Proposition 1 provides a generalisation of a variety of results that have already been derived for a homogeneous oligopoly. ${ }^{8}$ Inspection of eqs. (9) and (10) reveals that in the decentralised and intermediate centralised wage-setting regimes the firmspecific wage outcomes are decreasing in the firm-specific labour-input-coefficients $c_{i}$. The reason is that the union's marginal cost of a wage increase, $\partial l_{i} / \partial w_{i}$, unambiguously increases with $c_{i}$. That is the higher the labour-input-coefficient the larger is

\footnotetext{
${ }^{7}$ The first-order conditions are relegated to the Appendix.

${ }^{8}$ See e.g. Corneo (1998) among others, who derives expressions for $w_{i}^{C}$ and $w_{i}^{D}$ under the assumption $c_{i}=1$ for all $i$. Moreover, our analysis generalises the results of Haucap and Wey (2004), who consider the case $n=2, c_{1}=(1-d)$ and $c_{2}=1$.
} 
the incentive to lower the firm-specific wage $w_{i}$ in order to improve firm's $i$ competitive position in the product market. Conversely, if $c_{i}$ decreases, this induces unions in regimes $(D)$ and $(I)$ to settle for a higher wage as the marginal cost of a wage increase in terms of foregone employment is reduced. Moreover, in the decentralised regime $(D)$ the firm-specific wage is the higher the lower firm's $i$ labour-input-coefficient $c_{i}$ relative to the industry average, $\bar{c}$. The reason is that in the decentralised case unions generally have an incentive to cut wages in order to gain a larger share of industry employment. A low average industry productivity lowers this incentive by reducing the competitive pressure on firm $i$ thereby enabling its union to settle for a higher wage. Note that this is not the case in the intermediate centralised regime $(I)$, where the wage is solely a function of each firm's own labour-input-coefficient $c_{i}$. The intuition behind this result is that the competitive mechanism being at work in the decentralised regime completely disappears with an industry-wide union which fully internalises positive externalities arising from wage increases in firm $i$ for the employment level in the rival firms $j, j \neq i$. Eq. (11) shows that in the completely centralised regime $(C)$ the uniform industry-wage is a function of the average industry labour-input-coefficient $\bar{c}$ and the variability in productivity conditions, as measured by $V A R(c)$. Note that in a homogeneous industry with all firms exhibiting an identical labour-input-coefficient $\bar{c}$, the uniform industry wage reduces to

$$
w^{C}=\frac{\bar{w}}{2}+\frac{a}{2 \bar{c}}
$$

Compared to the wage outcome in a homogeneous industry with all firms exhibiting an identical labour-input-coefficient $\bar{c}$, an industry union in a heterogeneous industry therefore settles for a lower wage, since $V A R(c)>0 .{ }^{9}$ Proposition 2 establishes the ranking of equilibrium wage outcomes under the three regimes, as $n$ becomes large:

\footnotetext{
${ }^{9}$ The intuition behind this result is that an industry-union setting a uniform industry-wage takes into account the marginal cost of a wage increase for all firms in the industry, that is also for those firms which have a labour-input-coefficient above the average. Employment in those firms is affected more than proportionally negatively after a given wage increase. The reason is that a wage increase does not only reduce the output level to a larger extent, but also implies for a given output reduction a higher employment loss $\left(\right.$ since $\left.l_{i}=c_{i} q_{i}\right)$.
} 
Proposition 2 The limits of equilibrium wage outcomes in regimes $r=D, I, C$ for any given $c_{i}$ are:

(i)

$$
\lim _{n \rightarrow \infty} w_{i}^{D}=\frac{\bar{w}}{2}+\frac{\bar{w} \cdot \bar{c}}{2 c_{i}}
$$

(ii)

$$
\lim _{n \rightarrow \infty} w_{i}^{I}=\frac{\bar{w}}{2}+\frac{a}{2 c_{i}}
$$

(iii)

$$
\lim _{n \rightarrow \infty} w_{i}^{C}=\frac{\bar{w}}{2}+\frac{a}{2 \bar{c}}
$$

The limits of equilibrium wage outcomes under regimes $r=D, I, C$ lead to the following ranking as $n$ becomes large:

(iv)

$$
w_{i}^{I}>w_{i}^{D} \text { for all } c_{i}
$$

(v)

$$
w_{i}^{C}>(<) w_{i}^{I} \text { for } c_{i}>(<) \bar{c}
$$

Proof. See the Appendix.

The intuition behind part (iv) is as follows: the competitive mechanism being at work in the decentralised regime completely disappears with an industry-wide union which coordinates wage demands while setting wages at the firm level. Since an industry union fully internalises positive externalities arising from wage increases in one firm for the employment level in rival firms, wages in regime $(I)$ are unambiguously higher than in regime $(D)$ for any given $c_{i}$. Moreover, whether the uniform industry wage under regime $(C)$ turns out to be higher or lower than in regime $(I)$ for a given $c_{i}$ depends on the relationship between $c_{i}$ and the average labour-input-coefficient, $\bar{c}$ (see part $(v)$ ). The reason is that in regime $(I)$ the industry union adjusts wages to local conditions at the firm level. In sum, part $(i v)$ and $(v)$ of Proposition 2 suggest that an unambiguous ranking $\left(w_{i}^{C}>w_{i}^{I}>w_{i}^{D}\right)$ may be derived only for $c_{i}>\bar{c}$. If $c_{i}<\bar{c}$, we have $w_{i}^{C}<w_{i}^{I}$ and $w_{i}^{D}<w_{i}^{I}$, but the relationship between $w_{i}^{C}$ and $w_{i}^{D}$ remains ambiguous. In particular, if $c_{i}$ is small relative to $\bar{c}$, regime $(D)$ may lead to higher wages as a centralised union's wage demand is oriented towards the average labour-input-coefficient $\bar{c}$.

Proposition 1 and 2 have dealt with the equilibrium wage levels under the three wage-setting structures. However, our main question is whether the extent of rentsharing is likely to differ across the regimes. To obtain some theoretical guidance on whether the sensitivity of wages to firm-specific conditions is likely to differ across 
the regimes, Proposition 3 compares the wage responses to firm-specific productivity and profitability conditions ${ }^{10}$ :

Proposition 3 Differentiating the equilibrium wage outcomes under the three wagesetting structures $r=D, I, C$ with respect to $c_{i}$, we obtain:

(i)

$$
-\frac{d w_{i}^{D}}{d c_{i}}=\frac{a(2 n+1)+n^{2} \bar{w} \cdot \bar{c}}{(2 n+1)(n+1) c_{i}{ }^{2}}>\frac{d w_{i}^{C}}{d c_{i}}=0,-\frac{d w_{i}^{I}}{d c_{i}}=\frac{a}{2 c_{i}{ }^{2}}>\frac{d w_{i}^{C}}{d c_{i}}=0
$$

(ii)

$$
\left|\frac{d w_{i}^{I}}{d c_{i}}\right|>\left|\frac{d w_{i}^{D}}{d c_{i}}\right|, \text { if } \frac{a\left(2 n^{2}-n-1\right)}{\bar{w} 2 n^{2}}>\bar{c} .
$$

(iii) With $R_{i}=\left(P q_{i}-\bar{w} l_{i}\right) / l_{i}=P / c_{i}-\bar{w}$ denoting per-capita quasi-rents in firm $i$, we obtain:

$$
\frac{d w_{i}^{C}}{d R_{i}^{C}}=0 \text { and } \frac{d w_{i}^{I}}{d R_{i}^{I}}>\frac{d w_{i}^{D}}{d R_{i}^{D}}, \text { if } \frac{a\left(2 n^{2}-n-1\right)}{\bar{w} 2 n^{2}}>\bar{c} .
$$

Proof. See the Appendix.

Corollary $4 d w_{i}^{I} / d R_{i}^{I}>d w_{i}^{D} / d R_{i}^{D}$ as $n$ becomes large.

Proof. By virtue of eq. (4), a necessary condition for industry output $Q$ to be positive is $\frac{a}{\bar{w}}>\bar{c}$. With $\lim _{n \rightarrow \infty} \frac{\left(2 n^{2}-n-1\right)}{2 n^{2}}=1$ and eq. (20), we obtain $d w_{i}^{I} / d R_{i}^{I}>d w_{i}^{D} / d R_{i}^{D}$ if $n \rightarrow \infty$.

Proposition 3 and Corollary 4 are straightforward to interpret. While regimes $(D)$ and $(I)$ allow for wage flexibility at the firm level, the completely centralised regime $(C)$ suppresses any wage response to firm-specific productivities, since the uniform industry wage applies to all firms in the industry (part $(i)$ ). Part (iii) reveals that the same result holds for responses to firm-specific profitability measures, since changes in $c_{i}$ directly feed into changes of per-capita quasi rents ${ }^{11}$. According to part $(i i)$ and ( $i i i)$, the difference between wages responses to firm-specific conditions under regimes $(I)$ and $(D)$ is generally ambiguous. However, when differentiating $-d w_{i}^{D} / d c_{i}$ with respect to $n$ it can be shown that the wage reaction in the decentralised case decreases with the number of firms in the industry, $n$. The mechanism at work here is that a more competitive product market restricts a firm-specific union's ability to

\footnotetext{
${ }^{10}$ In particular, those results are derived under the assumption that the average labour-inputcoefficient $\bar{c}$ in the industry is held constant. The motivation is that in the empirical analysis we want to measure the extent to which the within-industry variability of wages can be explained by the within-industry variability of profitability measures. Wage effects of differences in $\bar{c}$ over time and across industries will be captured by including time- and industry dummies.

${ }^{11}$ We employ quasi-rents as our preferred profitability measure (as compared to profits), because in the empirical analysis we want to circumvent the endogeneity problem induced by the accounting relationship between wages and profits.
} 
raise the wage in response to a higher productivity level (or a lower $c_{i}$ ), since the marginal cost of a given wage increase is positively related to the number of firms in the industry. Conversely, in the intermediate centralised case this competitive mechanism disappears and the wage response solely depends on the productivity level and the overall level of industry demand, parameterised by $a$. Thus, as $n$ becomes large, an industry union that coordinates wage demands at the industry level (regime $(I)$ ) is likely to benefit to a larger extent from a given productivity increase. As a consequence, this entails higher wage responses than in regime $(D)$. From Proposition 3 and Corollary 4 we derive the following central hypotheses for our empirical analysis:

Hypothesis 1: The sensitivity of wages to firm-specific conditions is likely to be the larger the more coordinated and decentralised the wage-setting process. Therefore, we expect wages under firm-specific contracts (regime $(I)$ ) to react stronger to local profitability conditions than in non-covered firms (regime $(D)$ ).

Hypothesis 2: Under the adoption of flexibility provisions we expect wages under centralised contracts (regime $(I)$ ) to be more sensitive to firm-specific profitability conditions than in non-covered firms. Conversely, without any adoption of flexibility provisions wages under centralised contracts are expected to be completely unresponsive to firm-specific quasi-rents (regime $(C)$ ).

\section{Empirical Analysis}

\subsection{Empirical Model and Testable Hypotheses}

In order to quantify the relationship between firm-specific profitability and wages across different wage-setting regimes, we impose a wage equation taking the basic form

$$
w_{i t}=\alpha+\beta_{\pi} \cdot \pi_{i t}+\boldsymbol{\gamma} \cdot \mathbf{x}_{i t}^{\prime}+\boldsymbol{\delta} \cdot \mathbf{z}_{i t}^{\prime}+\lambda \cdot D_{t}+f_{i}+u_{i t} .
$$

Since we will use establishment level panel data, all variables are subscripted by a firm-index $i$ and a time index $t$. The dependent variable, $w$, is the firm-specific average wage per worker. The explanatory variable of main interest is $\pi$, measuring firm-specific per-capita profitability. The theoretical results from Proposition 1 suggest that in regimes $(D)$ and $(I)$ equilibrium wages ought to be a direct function of firm-specific productivity measures, $c_{i}$. However, as we are not interested in estimating a structural model and since we want to compare our quantitative results to other results obtained in the empirical rent-sharing literature, we explain wages by firm-specific per-capita profitability measures. To measure firm-specific profitability, we use quasi-rents - defined as value-added minus the opportunity cost of labour ${ }^{12}$ for two reasons. First, in part ( $i i i$ ) of Proposition 3 it has been shown that this is appropriate from a theoretical point of view, since firm-specific productivity differentials feed into firm-specific per-capita quasi-rent-differentials. Second, using quasi-rents instead of profits turns out to be advantageous from an econometric perspective. This

\footnotetext{
${ }^{12}$ Compare part (iii) of Proposition 3 as well as data and variable description below.
} 
is because netting-out the opportunity cost of labour instead of wages eliminates one important source of endogeneity inherent in profits which are negatively correlated to wages by construction (see Abowd and Lemieux 1993).

In eq. (21), $\mathbf{x}^{\prime}$ represents a (column) vector of further firm characteristics with a coefficient vector $\gamma$, while $\mathbf{z}^{\prime}$ denotes a vector of industry characteristics with a coefficient vector $\boldsymbol{\delta}$. For $\mathbf{z}^{\prime}$ we include the average sectoral wage as a proxy for the alternative wage, $\bar{w}$, as well as industry dummies. The latter are supposed to capture industry-specific factors, such as the overall level of industry demand and the degree of competition which are are likely to impact upon wages as reflected by the equilibrium wage outcomes in Proposition 1. The vector of firm-specific characteristics, $\mathbf{x}^{\prime}$, includes among other variables dummies for the three wage-setting regimes as suggested by Proposition 1. Moreover, as our theoretical model assumes homogeneous workers, $\mathbf{x}^{\prime}$ contains shares of different skill groups and shares of female workers to control for firm-specific compositions of the workforce. To account for unobserved differences in worker quality and differences in technologies, further firm-specific explanatory variables include firm size and the capital-labour ratio. Time dummies $D_{t}$ are included to capture common macroeconomic shocks, and $u_{i t}$ is a serially uncorrelated white-noise error term. Finally, firm-specific fixed effects $f_{i}$ are added to eq. (21) in order to capture unobserved time-invariant firm-specific factors.

Since the emphasis of our analysis is on the impact of different wage-setting regimes on the sensitivity of wages to firm-specific profitability conditions, the profit coefficient $\beta_{\pi}$ is specified to depend on the wage-setting regime:

$$
\beta_{\pi}=\beta_{0}+\beta_{\pi_{-} C E N T} \cdot C E N T_{i t}+\beta_{\pi_{-} D E C E N T} \cdot D E C E N T_{i t},
$$

where $C E N T$ is a dummy taking the value of unity if a firm adopts a centralised collective wage agreement and DECENT takes the value of unity if a firm is party to a firm-specific collective wage contract. This implies that $\beta_{0}+\beta_{\pi}$ CENT measures the sensitivity of wages to firm-specific profits in firms covered by a centralised wage contract, whereas $\beta_{0}+\beta_{\pi} D E C E N T$ reflects the degree of rent-sharing in firms covered by a firm-specific wage agreement. Finally, the degree of rent-sharing in firms without any bargaining coverage is measured by $\beta_{0}$. Recall that according to the theoretical results derived in Section 3, the sign of $\beta_{\pi_{D} D E C E N T}$ is - strictly speaking - ambiguous (part (ii) of Proposition 3). However, according to Corollary 4 and Hypothesis 1 wage reactions to firm-specific profitabilities are larger in regime $(I)$ than in regime $(D)$ as $n$ becomes large. As a consequence, we expect $\beta_{\pi}$ DECENT to be positive. This expectation is even enforced by the fact that wage-setting actors in regime $(D)$ presumably have lower bargaining power than unions in regime $(I) .{ }^{13}$

Whether $\beta_{\pi}{ }_{C E N T}$ is positive or negative cannot be predicted a-priori, since this depends on the fraction of firms making use of flexibility provisions in centralised wage

\footnotetext{
${ }^{13}$ Note that the theoretical results rely on the assumption that unions have the whole bargaining power. Insofar, our theoretical predictions with respect to the degree of rent-sharing provide an upper bound of the responsiveness of wages to profits.
} 
agreements. Unfortunately, in our data, direct information on the use of flexibility provisions in firms subject to a centralised wage agreement is unavailable (see next section). In particular, we expect $\beta_{\pi_{C E N T}}$ to be positive, if the adoption of flexibility provisions is an empirically relevant phenomenon, because this case reflects wagesetting regime $(I)$. Conversely, testing $\beta_{\pi} C E N T=-\beta_{0}$ provides a direct test of a zero wage-response to firm-specific conditions, as predicted by regime $(C)$. In this regard, we will interpret our empirical findings as an indirect test of whether the use of flexibility provisions in central wage agreements is a quantitatively important phenomenon in Germany.

\subsection{Data and Variable Description}

The empirical analysis uses data from the IAB Establishment Panel. This data set is based on an annual survey of West-German establishments administered since 1993. Eastern German establishments entered the panel in 1996. The data base is a representative sample of German establishments employing at least one employee who pays social security contributions. The survey data are assembled in personal interviews and provide numerous information on establishment structure and performance, as for example the aggregate wagebill, sales, size and composition of the workforce (see e.g. Bellmann et al. 2002). Moreover, the data contain information on whether an establishment is covered by an industry-wide collective wage agreement, a firm-specific wage agreement or by no collective agreement at all. In our analysis we use data for the years 1995 to 2002, since detailed information on bargaining coverage is available only from 1995 on. Because information on a number of variables, as e.g. sales and the share of materials in total sales are gathered retrospectively for the preceding year, we lose information on the last year. Moreover, we restrict our sample to mining and manufacturing establishments with at least two employees. As we will apply dynamic panel data methods, only establishments with consistent information on the variables of interest and at least four consecutive time series observations are included in our sample. This results in a sample of 661 establishments with 3411 observations, yielding an unbalanced panel containing establishment-observations with, on average, 5.16 years of data. ${ }^{14}$

The variables used in the subsequent empirical analysis are defined as follows. The dependent variable, $w$, is defined as the annual aggregate wagebill divided by the number of employees. The number of employees and the wagebill are reported for the month June, where the wagebill is defined exclusive of employers' mandatory social security contributions as well as fringe benefits. ${ }^{15}$ Following part (iii) of Proposition 2 , firm profitability, $\pi$, is measured by per-capita quasi-rents. Those are constructed

\footnotetext{
${ }^{14}$ Originally, the sample includes 3546 establishments with consistent information on all the variables of interest. 21 observations were dropped due to suspected errors in the firm size variable. These observations featured per-capita values of rents of above 1 million DM. For the same reason, 81 observations with a per-capita wagebill of below 8000 DM were discarded from the sample. This results in a sample of 3515 establishments with a total of 8617 observations. Only 661 of those feature at least four consecutive time-series observations.

${ }^{15}$ Monthly values are converted into annual values by multiplying them with the factor 12 .
} 
as the difference between annual sales, material costs and the alternative annual wagebill divided by firm size, so that

$$
\pi=\frac{S A L E S-M A T E R I A L C O S T-\bar{w} \cdot S I Z E}{S I Z E} .
$$

Firm size $(S I Z E)$ is calculated as the reported number of employees averaged over the present and preceding year. The alternative wagebill, $\bar{w} \cdot S I Z E$, is defined as the annual wagebill which each firm would incur if it had to pay the average industrial wage. Thus, we approximate $\bar{w}$ by the weighted average of industry-specific wages for blue- and white-collar workers with the weights being the firm-specific shares of those worker groups in the total work force. ${ }^{16}$ All monetary values are expressed as real values by deflating them with a sector-specific producer price index normalised to 1 in 2000. Industry specific price indices and wages are obtained from the Federal Statistical Office Germany and are matched to the firm-data on the basis of a twodigit sector classification (WZ 93).

Further variables include the share of high-skilled workers (defined as skilled whitecollar workers $)^{17}$, the share of skilled blue-collar workers, the share of female workers and the share of apprentices in the total work force. Because we do not directly observe the capital stock, we need to construct a proxy. We measure firm capital by using the perpetual inventory method starting from the capital value in the first observation year and using the information on expansion investment in the following years. The initial capital value is proxied by dividing investment expenditures in each firm's first observation year by a pre-period growth rate of investment, $g$, and a depreciation rate of capital, $\delta^{18}$. Capital-stocks in subsequent periods are calculated by adding real expansion investment expenditures ${ }^{19}$. To obtain real values, nominal investment expenditures are deflated by the producer price index of investment goods of the Federal Statistical Office Germany. The capital-labour ratio, $K / L$, is constructed by dividing the resulting capital proxy by firm size. An ownership dummy variable takes the value of unity in case of a privately owned company.

Table 2 presents sample statistics for the main variables used in the subsequent analysis. The figures disclose that quasi-rents vary considerably more than aver-

\footnotetext{
${ }^{16}$ We convert average hourly industrial wages of blue collar workers into monthly wages by multiplying them with firm-specific average working time. Since information on average sectoral wages of white-collar workers is available only on a monthly basis, we are not able to adjust those wages for firm-specific average working time. As with the dependent variable, monthly values are converted into annual values by multiplying them with the factor 12 .

${ }^{17}$ Unfortunately, more precise information on educational attainment is not available, as the data merely distinguish fractions of skilled and unskilled blue- and white-collar workers.

${ }^{18}$ This involves the assumption that investment expenditures on capital have grown at a constant average rate, $g$, so that the capital stock in the base year is $K_{1}=I_{0}+(1-\delta) I_{-1}+(1-\delta)^{2} I_{-2}+$

$\ldots=I_{1} \sum_{s=0}^{\infty}\left[\frac{1-\delta}{1+g}\right]^{s}=I_{1} /(\delta+g)$. In particular, to calculate $K_{1}$, we set $\delta=0.1$ and $g=0.05$ (see Hempell 2002).

${ }^{19}$ More specifically, $K_{t}=K_{t-1}(1-\delta)+I_{t-1}=K_{t-1}+E I_{t-1}$, where $K_{t}$ is the capital stock at the beginning of period $t$, i.e. at the end of period $t-1$, and $E I_{t}$ are expansion investment expenditures in period $t$.
} 
age wages. With respect to collective bargaining coverage, the fraction of firmobservations covered by an industry-wide wage agreement amounts to about 62 per cent, while the fraction of observations with a firm-specific agreement is only 11 per cent. 27 per cent of all observations are subject to no agreement at all. Breaking down the sample into those firms adopting an industry-wide agreement, a firm-specific agreement and into those without any bargaining coverage reveals that average wages are highest under industry-wide agreements and lowest without bargaining coverage (see Table A1 in the Appendix). The variability in wages is higher in firms under no bargaining coverage with a coefficient of variation of 0.46 as compared to 0.32 and 0.33 in firms with bargaining coverage. Moreover, firms under centralised agreements outperform those under firm-specific and those without bargaining coverage in terms of per-capita quasi-rents. Firms adopting industry-wide agreements also have more employees and exhibit the largest fraction of high-skilled workers, while firms without bargaining coverage employ on average more women than firms covered by an collective wage agreement. Finally, firms under firm-specific bargaining coverage feature the largest capital-labour ratio.

\begin{tabular}{llrrr} 
Variable & Definition & Mean & Std.-Dev. & Obs. \\
\hline \hline$w$ & Per-capita wagebill & 49.74 & 18.84 & 3411 \\
$\pi$ & Per-capita quasi-rents & 69.25 & 94.95 & 3411 \\
$\bar{w}$ & Alternative wage & 52.51 & 11.60 & 3411 \\
HIGHSHARE & Share of skilled white-collar workers & 0.25 & 0.20 & 3411 \\
BLUESHARE & Share of skilled blue-collar workers & 0.42 & 0.23 & 3411 \\
APPSHARE & Share of apprentices & 0.05 & 0.06 & 3411 \\
FEMSHARE & Share of female workers & 0.27 & 0.21 & 3411 \\
SIZE & Firm size & 605.80 & 2505.35 & 3411 \\
CENT & Centralised collective agreement & 0.62 & 0.49 & 3411 \\
DECENT & Firm-specific collective agreement & 0.11 & 0.32 & 3411 \\
WCOUNCIL & Works council & 0.64 & 0.48 & 3411 \\
K/L & Capital-labour ratio & 249.94 & 1344.08 & 3411 \\
EAST & Eastern Germany & 0.34 & 0.47 & 3411 \\
OWN & Private ownership & 0.21 & 0.41 & 3411 \\
\hline \hline
\end{tabular}

Source: IAB-Establishment Panel 1995-2002. Data processing through the Research Data Centre (FDZ) of the Federal Employment Services (BA) at the Institute for Employment Research (IAB), Nuremberg.

Note: All monetary values are measured in 1000 DM. $1 \in$ corresponds to 1.95583 DM.

Table 2: Descriptive statistics

\subsection{Results}

\subsubsection{Estimation Strategy}

We first focus on a simple static pooled Ordinary Least Squares (POLS) specification of eq. (21), without taking into account unobserved firm-specific effects and the 
endogeneity of our profit measure. The POLS estimations serve as a benchmark case and will be modified in various respects: first, we will address the possibility of unobserved firm-specific time invariant factors. In our context, the presence of unobserved heterogeneity may result from neglected capital costs in the rent measure as well as from differences in technological conditions ${ }^{20}$ and worker quality that are not captured by our control variables. As such unobserved factors are likely to be correlated with our profitability measure, simple POLS estimates may be expected to yield biased estimates of $\beta_{\pi}$. A second problem concerns the endogeneity of per-capita rents, because under the right-to-manage assumption wages, employment and rents are simultaneously determined. Since higher wages generally will reduce rents, POLS estimates will understate the true effect of rents on wages. Third, we will consider more dynamic specifications and will include lagged wages and rents as explaining variables in our wage regression. The inclusion of lagged rent measures and lagged wages is meant to allow for possible dynamics in the reaction of wages to profitability conditions and sluggish adjustment of wages.

\subsubsection{Pooled OLS-Results}

Table 3 reports results from POLS estimations of the impact of quasi-rents per worker on wages. The variables are specified in levels rather than logs, since the use of logs would have required discarding all observations with negative quasi-rents.

The estimate of quasi-rents per employee on the average wage is 0.049 when including only the alternative wage in the regression. Adding firm-level worker characteristics reduces the coefficient to 0.040, suggesting that around 20 per cent of the correlation between rents and wages is due to systematic sorting of workers across firms (Model (2)). In particular, high-qualified workers appear to be associated with more profitable firms. The effects of rents on wages are further reduced when including other firm characteristics, such as firm size, bargaining coverage, the existence of a works council and ownership status (Model (3)). Apart from BLUESHARE (fraction of skilled blue-collar workers), the capital-labour ratio $K / L$ and $D E C E N T$, all control variables enter the regression with their expected sign and are all significant at the 1 per cent level. Firm size is found to have a significant positive effect on average wages, a result which is consistent with earlier evidence. ${ }^{21}$ In the literature, various explanations have been advanced for a positive relationship between firm size and wages, such as differences in profits, capital equipment, worker quality and monitoring costs among others. ${ }^{22}$ As we control explicitly for differences in work force compositions, the capital-labour ratio and quasi-rents, the firm size variable may be

\footnotetext{
${ }^{20}$ With respect to differences in technologies, firm-specific fixed effects capture e.g. production processes that provide firms with higher rents and which may require compensating wage differentials (e.g. processes involving dangerous work). Such differences might lead to a positive wage-rent correlation which would not be due to rent-sharing (see e.g. Margolis and Salvanes 2001).

${ }^{21}$ For German evidence on employer size effects see e.g. Schmidt and Zimmermann (1991) and Gerlach and Hübler (1998).

${ }^{22}$ For an overview see e.g. Oi and Idson (1999).
} 


\begin{tabular}{|c|c|c|c|c|c|c|}
\hline Model & 1 & 2 & 3 & 4 & 5 & 6 \\
\hline \multirow[t]{2}{*}{$\pi$} & $0.049^{* * *}$ & 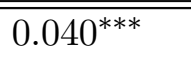 & 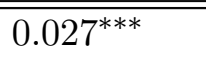 & 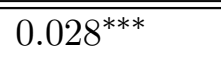 & $0.028^{* * *}$ & 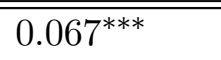 \\
\hline & $(0.004)$ & $(0.004)$ & $(0.003)$ & $(0.003)$ & $(0.003)$ & $(0.011)$ \\
\hline \multirow[t]{2}{*}{$\pi * \mathrm{CENT}$} & & & & & & $-0.046^{* * *}$ \\
\hline & & & & & & $(0.011)$ \\
\hline \multirow[t]{2}{*}{$\pi *$ DECENT } & & & & & & $-0.035^{* * *}$ \\
\hline & & & & & & $(0.012)$ \\
\hline \multirow[t]{2}{*}{$\bar{w}$} & $0.902^{* * *}$ & $0.646^{* * *}$ & $0.563^{* * *}$ & $0.690^{* * *}$ & $0.524^{* * *}$ & $0.529^{* * *}$ \\
\hline & $(0.024)$ & $(0.030)$ & $(0.028)$ & $(0.038)$ & $(0.065)$ & $(0.064)$ \\
\hline \multirow[t]{2}{*}{ HIGHSHARE } & & $14.090^{* * *}$ & $9.965^{* * *}$ & $7.656^{* * *}$ & $11.652^{* * *}$ & $11.371^{* * *}$ \\
\hline & & $(1.735)$ & $(1.563)$ & $(1.655)$ & $(1.976)$ & $(1.942)$ \\
\hline \multirow[t]{2}{*}{ BLUESHARE } & & $-2.746^{* *}$ & -1.020 & 1.384 & $2.029^{*}$ & $2.068^{*}$ \\
\hline & & $(1.205)$ & (1.088) & (1.098) & $(1.123)$ & $(1.124)$ \\
\hline \multirow[t]{2}{*}{ APPSHARE } & & $-13.457^{* * *}$ & $-6.126^{*}$ & 2.003 & -4.940 & -4.612 \\
\hline & & $(3.711)$ & $(3.271)$ & $(3.536)$ & $(4.019)$ & $(4.004)$ \\
\hline \multirow[t]{2}{*}{ FEMSHARE } & & $-20.904^{* * *}$ & $-17.904^{* * *}$ & $-16.790^{* * *}$ & $-16.969^{* * *}$ & $-16.800^{* * *}$ \\
\hline & & $(1.235)$ & $(1.113)$ & $(1.255)$ & $(1.250)$ & $(1.240)$ \\
\hline \multirow[t]{2}{*}{ SIZE } & & & $0.002^{* * *}$ & $0.002^{* * *}$ & $0.002^{* * *}$ & $0.002^{* * *}$ \\
\hline & & & $(0.0003)$ & $(0.0003)$ & $(0.0003)$ & $(0.0003)$ \\
\hline \multirow[t]{2}{*}{ SIZE $^{2}$} & & & $-2.87 e^{-08 * *}$ & $-3.44 e^{-08 * * *}$ & $-3.32 e^{-08 * * *}$ & $-3.29 e^{-08 * * *}$ \\
\hline & & & $\left(1.16 e^{-08}\right)$ & $\left(1.16 e^{-08}\right)$ & $\left(1.17 e^{-08}\right)$ & $\left(1.18 e^{-08}\right)$ \\
\hline \multirow[t]{2}{*}{ CENT } & & & $4.566^{* * *}$ & $4.749^{* * *}$ & $4.331^{* * *}$ & $6.335^{* * *}$ \\
\hline & & & $(0.633)$ & $(0.640)$ & $(0.649)$ & $(0.705)$ \\
\hline \multirow[t]{2}{*}{ DECENT } & & & 0.808 & $1.285^{*}$ & 1.107 & $2.256^{* *}$ \\
\hline & & & $(0.780)$ & $(0.766)$ & $(0.765)$ & $(0.896)$ \\
\hline \multirow[t]{2}{*}{ WCOUNCIL } & & & $7.017^{* * *}$ & $7.317^{* * *}$ & $6.987^{* * *}$ & $6.901^{* * *}$ \\
\hline & & & $(0.652)$ & $(0.647)$ & $(0.651)$ & $(0.644)$ \\
\hline \multirow[t]{2}{*}{$\mathrm{K} / \mathrm{L}$} & & & 0.00004 & $0.0003^{* *}$ & $0.0002^{*}$ & $0.0002^{*}$ \\
\hline & & & $(0.0001)$ & $(0.0001)$ & $(0.0001)$ & $(0.0001)$ \\
\hline \multirow[t]{2}{*}{ OWN } & & & $-3.720^{* * *}$ & $-3.901^{* * *}$ & $-3.861^{* * *}$ & $-3.827^{* * *}$ \\
\hline & & & $(0.548)$ & $(0.547)$ & $(0.541)$ & $(0.540)$ \\
\hline \multirow[t]{2}{*}{ EAST } & & & & & $-3.430^{* * *}$ & $-3.432^{* * *}$ \\
\hline & & & & & $(1.027)$ & $(1.019)$ \\
\hline Ind.-/Time & No & $\mathrm{No}$ & No & Yes & Yes & Yes \\
\hline Adj. $\mathrm{R}^{2}$ & 0.433 & 0.487 & 0.572 & 0.591 & 0.592 & 0.598 \\
\hline Observations & 3411 & 3411 & 3411 & 3411 & 3411 & 3411 \\
\hline Firms & 661 & 661 & 661 & 661 & 661 & 661 \\
\hline
\end{tabular}

Note: The dependent variable is the aggregate per-capita wagebill. Heteroscedasticity-robust standard-errors are in parentheses.

${ }^{*}$ Significant at $10 \%$-level.

** Significant at 5\%-level.

*** Significant at $1 \%$-level.

Table 3: Pooled OLS Regression Results 
interpreted as capturing some part of unobserved worker quality and technology differences. In Model (4), including industry and time dummies leaves the coefficient on rents largely unchanged. The invariance of the rent-coefficient against the inclusion of industry dummies suggests that rent-sharing in Germany mainly takes place within industries. Including an east-west dummy does not change the coefficient on rents either (Model (5)). Adding industry and time dummies and an east-west dummy in Model (4) and (5) changes the coefficient on BLUESHARE to its expected sign, indicating some systematic differences in workforce compositions across industries and regions.

As far as the bargaining coverage effects are concerned, the results in Proposition 2 suggest that the impact of the bargaining regime on the wage level should generally depend on whether firms feature higher or lower labour productivities than the industry average. However, in the empirical specification we do not allow the coefficients of the intercept dummies CENT and DECENT to vary with productivity measures as the main focus of our analysis will be on the rent-coefficient. Instead, we choose to estimate the average impact of centralised and firm-specific collective wage agreements on wages. In all models (except for model (3) and (5)), the estimates of the bargaining coverage coefficients are significant and are positive as expected from the theoretical analysis. ${ }^{23}$ In addition to the collective bargaining regime, we control for the existence of a works council. Those are found to exert a positive impact on averages wages, which is also in line with earlier studies. ${ }^{24}$

Finally, our main interest concerns the question whether the rent-coefficient differs systematically across the three wage-setting structures. The results from Model (6), which includes interactions between collective bargaining coverage and rents, indicate that the extent to which wages react to firm-specific profitability conditions is significantly lower in firms that are covered by a collective wage agreement. Surprisingly, even in firms covered by a firm-specific contract wages appear to be less sensitive to rents, which stands in contrast to our hypotheses derived in Section 3. Moreover, the adoption of a centralised and a firm-specific wage agreement seems to reduce the magnitude of rent-sharing to a similar extent, as a Wald-Test of $\beta_{\pi} C_{E N T}=\beta_{\pi}$ DECENT cannot be rejected at conventional levels (with a $p$-value of 0.108 ). However, the null hypotheses of $\beta_{0}=-\beta_{\pi} C E N T$ and $\beta_{0}=-\beta_{\pi}$ DECENT are rejected (with $p$-values of zero), suggesting that the overall impact of rents on wages is still positive under both regimes.

\subsubsection{Dynamic Specifications}

This section addresses potential econometric problems, such as the possibility of unobserved firm-specific time invariant factors as well as the endogeneity of rents. A further possible endogenous regressor is firm size, as higher wages are likely to induce firms to reduce their labour force. Moreover, to allow for sluggish adjustment of wages and time lags in the response of wages to profitability conditions, we add

\footnotetext{
${ }^{23}$ See the results of Proposition 2 evaluated at the average industry labour coefficient $\bar{c}$.

${ }^{24}$ See e.g. Addison et. al (2001) and Hübler and Jirjahn (2003).
} 
lagged wages and quasi-rents as explanatory variables to our regression. The wage equation then takes the following form

$$
w_{i t}=\alpha+\beta_{w} w_{i t-1}+\sum_{k=0}^{K} \beta_{\pi t-k} \cdot \pi_{i t-k}+\gamma \cdot \mathbf{x}_{i t}^{\prime}+\boldsymbol{\delta} \cdot \mathbf{z}_{i t}^{\prime}+\lambda \cdot D_{t}+f_{i}+u_{i t},
$$

where the coefficients $\beta_{\pi t-k}$ are specified as in eq. (22). First differencing eq. (24) eliminates time-invariant firm-specific effects. As first differencing causes the lagged dependent variable $\Delta w_{i t-1}$ to become correlated with the error term $\Delta u_{i t}$, it is necessary to instrument lagged wages. In the absence of second-order correlation in the error term, $w_{i t-2}$ and earlier lags will provide suitable instruments, since they will be uncorrelated with $\Delta u_{i t}$. Because rents, their interactions with the wage-setting regimes and firm size are likely to be endogenous, they are to be instrumented as well. As with the lagged dependent variable, suitable candidates are lagged rents and firm size in $t-2$ and earlier provided they do not enter eq. (24) as explanatory variables. Since this might be particularly relevant for lagged rents, we test for the significance of rents up to $t-2$.

To estimate eq. (24), we first apply the differenced Generalized Methods of Moments (GMM) estimator as proposed by Arellano and Bond (1991). This estimator exploits all available moment conditions around the error term as specified above. Apart from instrumenting endogenous and lagged dependent variables by their lagged values in $t-2$, the GMM estimator provides an appropriate treatment of predetermined variables which are assumed to be uncorrelated with $u_{i t}$ and $u_{i t+1}$, but are correlated with $u_{i t-1}$. As first differencing causes such variables to become correlated with the error term $\Delta u_{i t}$, they are instrumented by lagged values in $t-1$ and earlier. In particular, we allow all human capital variables and the capital-labour ratio to be predetermined in order to capture potential feedback effects from wages in period $t$ on those covariates in subsequent periods. To test the validity of the moment conditions, we present the Sargan/Hansen test of overidentifying restrictions. This test statistic calculates the correlation of the error terms with the instrument matrix and has an asymptotic $\chi^{2}$ distribution under the null that the moment conditions are valid. Moreover, we report diagnostics for second-order serial correlation of the error terms (testing the null of no second-order serial correlation).

Table A2 in the Appendix gives the results of the differenced GMM estimates ${ }^{25}$. While Model (1) contains the static specification, Model (2) contains the simplest dynamic specification adding solely the lagged wage to the explanatory variables. Model (3) additionally includes lagged rents, while Model (4) contains lags of rents up to $t-2$. Table A2 contains estimates for time-varying regressors only, since firstdifferencing eliminates all time-invariant explanatory variables ${ }^{26}$.

\footnotetext{
${ }^{25}$ All estimations have been carried out using the "XTABOND2"-procedure in STATA 8.0 SE.

${ }^{26}$ In our sample, time-invariant variables are the ownership dummy, the east-west dummy and the industry dummies. The collective bargaining dummies and the works council dummy are time varying binary regressors.
} 
Turning to the main variables of interest, the signs of the rent-coefficients exhibit the same pattern as the POLS-estimates of Model (6) in Table 3. While the rent-coefficient is almost always significantly positive for non-covered establishments, wages appear to be less sensitive to rents in establishments that are covered by a collective wage agreement. Including the lagged wage as a further explanatory variable in Model (2) reduces the rent-coefficients somewhat. As mentioned earlier, using lagged rents in $t-2$ as instruments for contemporaneous rents requires that they do not enter eq. (24) as explanatory variables. To check the robustness of our findings, we therefore include lagged rents up to $t-2$ in Model (3) and (4). While lags of rents in $t-1$ are found to be insignificant in Model (3), lagged rents in $t-2$ enter Model (4) significantly, indicating that wages do not only respond to contemporary firm performance, but also to past profitability conditions. In Model (3), the effects of (contemporaneous) rents on wages in non-covered establishments are reduced, but remain still significant, once lagged rents up to $t-1$ are controlled for. However, controlling for rents up to $t-2$ in Model (4) leads to an imprecise estimate of the rent-coefficient in non-covered establishments. The last two rows in the first part of Table A2 report $p$-values of Wald-statistics testing the null of $\beta_{0}=-\beta_{\pi}$ CENT and $\beta_{0}=-\beta_{\pi}{ }_{D E C E N T}$ for the contemporaneous rent coefficients. The values indicate that wages appear to be completely insensitive to profitability conditions in establishments that are covered by a collective agreement, irrespective of whether the agreement is industry or firm-specific. Moreover, from the last rows in the second part of Table A2 it can be seen that all specifications pass the test of overidentifying restrictions and the $\mathrm{AR}(2)$-test.

However, with respect to the remaining covariates, the performance of the differenced GMM estimates turns out to be rather unsatisfactory: although the lagged wage enters specification (2) and (3) with its expected sign, it is not significant and its point estimates appear to be implausibly low. In Model (4), the estimate is even negative. In all specifications, firm size and the works-council dummy are always insignificant and for the most part incorrectly signed. The capital-labour ratio is found to be significant, but with a negative sign. As regards the workforce composition, the estimates of HIGHSHARE also seem to be poorly determined, as they enter all regressions negatively. The remaining controls for the workforce composition enter with their expected sign (except for BLUESHARE in Model (1)), but only APPSHARE turns out to be significant in Model (1).

In light of the poor performance of the differenced GMM-estimates, Table A3 reports results using the System-GMM (SYS-GMM) estimator as proposed by Arellano and Bover (1995). This estimator is motivated by the problem that lagged levels of a variable are likely to be weak instruments for the equation in first differences if the individual time series exhibits near unit root properties. Closer inspection of the time-series properties of the main variables of interest reveals that particularly the firm size variable and the capital-labour ratio appear to be close to a random walk. ${ }^{27}$

\footnotetext{
${ }^{27}$ SYS-GMM estimates of a simple AR(1)-process yield a coefficient of about 0.94 of firm size and of 0.91 for the capital-labour ratio.
} 
The SYS-GMM estimator exploits additional moment conditions for the equation in levels using lagged differences as instruments in the levels equation. In particular, predetermined variables are instrumented by contemporaneous first differences in the levels equation, whereas endogenous and lagged dependent variables are instrumented by lagged first differences (Bond 2002). To test the additional moment conditions implied by the SYS-GMM estimator as compared to the differenced GMM estimates in Table A2, we present in each column difference tests which refer to the respective specifications in Table A2. The test statistics are calculated as the differences between the Sargan/Hansen statistics of the SYS-GMM and those of the differenced GMM estimates and have an asymptotic $\chi^{2}$ distribution under the null that the additional moment restrictions are valid.

Overall, the SYS-GMM estimates appear to be more satisfactory than the differenced GMM results. The lagged wage enters all specifications with its expected sign and its estimates are considerably higher than the differenced GMM estimates, suggesting that the latter are severely downward biased. In all specifications, firm size is found to have a significantly positive impact on average wages and is estimated much more precisely than in the differenced GMM specification. This is consistent with the random-walk property of this variable, indicating that the lagged level of firm-size is a weak instrument for first-differences. The same is true for the capitallabour ratio, which enters all regressions with its expected sign, but is significant only in the static Model (1). From the human capital covariates, only FEMSHARE and APPSHARE enter all regressions with their expected sign. The remaining worker controls are mostly incorrectly signed and not significant. Turning to the impact of rents on average wages, the estimates offer a similar picture as the differenced GMM results: in non-covered firm, quasi-rents exert a positive impact on wages, while wages are generally found to be less sensitive to rents in firms that are covered by a collective wage agreement. Compared to the differenced GMM results, the coefficients of lagged rents in $t-2$ turn out to be lower and are imprecisely estimated (Model (4)). Nevertheless, including the lagged wage and lags of rents up to $t-2$ improves the Sargan/Hansen-statistics testing the validity of overidentifying restrictions. Moreover, the difference Sargan/Hansen statistic testing the additional moment restrictions as compared to Table A2 confirms their validity only in Model (4) (with a $p$-value of 0.192).

Finally, Table A4 reports results assuming that all predetermined explanatory variables are uncorrelated with the time-invariant firm-specific effect. Again, difference statistics are reported to test the validity of the additional moment restrictions as compared to the estimates in Table A2. The difference statistics reveal that the validity of the additional moment restrictions can be accepted for all models, except Model (3) (with a $p$-value of 0.029). Moreover, in the dynamic specifications the $\mathrm{AR}(2)$-test is improved, once lags of rents up to $t-2$ are included. For this reason, we choose Model (4) as our preferred specification.

Overall, the estimates appear to be further improved. The point estimates of lagged wages are further increased while the standard errors remain largely un- 
changed. Except for the static specification, all human capital and firm covariates enter with their expected sign. The estimates of the rent-coefficients are similar to Table A3. Comparing the rent-sharing coefficients in covered and non-covered establishments, the pattern seems to be remarkably stable: the extent to which wages respond to firm-conditions turns out to be considerably lower in covered establishments. In specifications (2) to (4), a Wald-test fails to reject the null of a zerocoefficient on contemporaneous rents under centralised as well as firm-specific agreements $\left(\beta_{0}=-\beta_{\pi_{-} C E N T}\right.$ and $\left.\beta_{0}=-\beta_{\pi_{-} D E C E N T}\right)$. Only in Model (1), the null of a zero-coefficient can be rejected under centralised agreements (with a $p$-value of $0.037)$.

Comparing the GMM-estimates of the rent-sharing coefficients to the POLSestimates reveals that the POLS-estimates still yield positive estimates of the rentsharing coefficient in covered establishments, whereas the SYS-GMM-results accounting for unobserved heterogeneity and endogeneity of rents point to a rent-sharing coefficient of zero. This finding is indicative of the presence of unobserved factors in covered establishments which are positively correlated with profits and impact positively upon wages. One such factor may be that a compressed wage structure under centralised wage contracts causes firms to upgrade the quality of their workforce. This might lead to higher unobserved worker quality in such firms and therefore to upwardbiased estimates in the simple POLS-specification. Comparing the GMM-estimates of the rent-sharing coefficients to the POLS estimates in non-covered establishments points to remarkably similar figures. While the POLS-coefficient in non-covered establishments amounts to 0.067, the SYS-GMM-estimates in our preferred specification (Model (4)) are 0.071. This finding suggests that the upward bias caused by the presence of unobserved heterogeneity is slightly dominated by the downward bias due to the endogeneity of rents in the POLS specification. Given the coefficient 0.071 and mean wages and quasi-rents per employee of 38.78 and 34.97 in non-covered establishments, the elasticity of the average wage with respect to contemporaneous quasi-rents is of the magnitude 0.064 .

How does this result compare to other estimates for Germany? Hübler and König (1998) report an estimate of about 0.12, while Klodt (2000) finds an elasticity of 0.14. However, those studies do not allow the rent-coefficient to vary with collective bargaining coverage. Compared to these figures, our estimate of the contemporaneous rent-coefficient in non-covered establishments therefore appears to be rather low. However, given the variability of rents, our results suggest that the quantitative role of rent-sharing in wage determination is nevertheless substantial: calculating the share of variance in the distribution of wages due to the variability in rents, it can be shown that the variability in per-capita rents explains about 25.5 per cent of the variability in (average) firm-wages ${ }^{28}$.

\footnotetext{
${ }^{28}$ This calculation is performed under the assumption that 95 per cent of the mass of a symmetric distribution is within plus or minus 2 standard deviations of the mean. The contribution of the variability of rents to the variability of wages can then be calculated as:

$\frac{\beta_{\pi}\left(\bar{\pi}+2 \sigma_{\pi}\right)-\beta_{\pi}\left(\bar{\pi}-2 \sigma_{\pi}\right)}{\left(\bar{w}+2 \sigma_{w}\right)-\left(\bar{w}-2 \sigma_{w}\right)}=\frac{\beta_{\pi} \cdot \sigma_{\pi}}{\sigma_{w}}$ (see e.g. Margolis and Salvanes 2001).
} 
For centralised wage-agreements, the invariance of wages against firm-specific profitability indicates that the fraction of firms making use of flexibility provisions seems to be rather negligible. Even though firms may pay wages above the going rate and may adopt opting-out clauses, this potential for adjustments to local conditions at the firm-level appears to be largely unused. ${ }^{29}$ Even more surprising, however, is the invariance of wages against firm-profits in firms that are subject to a firm-specific wage contract. Although this result is to be interpreted with caution as the number of observations with a firm-specific wage contract is rather small, it stands in sharp contrast to our theoretical analysis suggesting that under firm-specific contracts the sensitivity of wages to profits ought to be even larger than in non-covered firms.

\section{$5 \quad$ Summary and Conclusions}

The aim of this paper was twofold: first, we have addressed the question of whether German wages respond to firm-specific profitability conditions and second, we have been interested in whether the sensitivity of wages to firm profits depends on collective bargaining coverage. To analyse these questions, we have set up a theoretical model that analyses the relationship between wages and firm-specific conditions under different wage-setting structures. The main result from our theoretical analysis is that the degree of rent-sharing is likely to be the larger the more coordinated the wage-setting process and the more decentralised the level of wage determination. We therefore expect wages to react stronger to local conditions in firms that are covered by a collective contract and where wages are determined at the firm-level than in non-covered firms. Since direct information on the use of flexibility provisions in firms subject to a centralised wage agreement is unavailable, we take our empirical findings as an indirect test of whether the use of flexibility provisions in central wage agreements is a quantitatively important phenomenon in Germany.

The results of our empirical analysis offer a remarkably consistent picture: in general, rent-sharing is found to be an empirically relevant phenomenon in Germany. However, the extent of rent-sharing seems to be significantly lower in firms that are subject to a collective wage agreement - irrespective of whether the agreement is industry- or firm-specific. While the POLS-estimates still yield positive estimates of the rent-sharing coefficient in covered firms, the GMM-results accounting for unobserved heterogeneity and endogeneity of rents point to a rent-sharing coefficient of zero. This finding is indicative of the presence of unobserved factors in covered firms which are positively correlated with profits and impact positively upon wages. One such factor may be that a compressed wage structure under centralised wage contracts causes firms to upgrade the quality of their workforce. This might lead to higher unobserved worker productivity in such firms and therefore to upward-biased estimates in the simple POLS-specification.

\footnotetext{
${ }^{29}$ This finding corroborates the results of Franz and Pfeiffer (2003), which are based on an employer survey of about 800 German firms. Their results indicate that only 18 per cent of those employers that covered by a collective contract allowing for hardship clauses make use of such provisions.
} 
For centralised wage-agreements, the invariance of wages against firm-specific profitability suggests that the use of flexibility provisions in central wage agreements appears to be empirically negligible. Even though firms may pay wages above the going rate and may make use of opting-out clauses, this potential for adjustments to local conditions at the firm-level appears to be largely unused. Even more surprising, however, is the invariance of wages against firm-profits in firms subject to a firm-specific wage contract. Although this result is to be interpreted with caution as the number of observations with a firm-specific wage contract is rather small, it stands in sharp contrast to our theoretical analysis suggesting that under firm-specific contracts the sensitivity of wages to profits ought to be even larger than in non-covered firms. As firm-specific contracts are generally concluded by sector-specific unions, one possible explanation might be that a considerable fraction of firm-specific contracts simply adopts wage bargains negotiated in the corresponding sector agreement. This could be due to high transaction costs of implementing firm-specific agreements which are not taken into account by our theoretical model. Furthermore, it might be conceivable that the internalisation of macroeconomic externalities prevents industry unions from excessive wage demands, even under firm-specific negotiations. Apart from these theoretical considerations, another answer to this puzzle might lie in the presence of unobserved heterogeneity that is not being taken into account by controlling for firm-level fixed effects. In this respect, it would be desirable to control not only for unobserved heterogeneity of firms but also on behalf of individual workers, which calls for the use of matched worker-firm data. 


\section{References}

[1] Abowd, J.M. and T. Lemieux (1993), The effects of product market competition on collective bargaining agreements: The case of foreign competition in Canada, The Quarterly Journal of Economics 108, 983-1014.

[2] Abowd, J.M., Kramarz, F. and D.N. Margolis (1999), High-wage workers and high-wage firms, Econometrica 67, 251-333.

[3] Addison, J.T., Schnabel, C. and J. Wagner (2001), Works councils in Germany: their effects on establishment performance, Oxford Economic Papers 53, 659-694.

[4] Arai, M. (2003), Wages, profits and capital-intensity: evidence from matched worker-firm data, Journal of Labor Economics 21, 593-618.

[5] Arellano, M. and S.R. Bond (1991), Some tests of the specification for panel data: Monte Carlo evidence and an application to employment equations, Review of Economic Studies 58, 277-297.

[6] Arellano, M. and O. Bover (1995), Another look at the instrumental-variable estimation of error-components models, Journal of Econometrics 68, 29-52.

[7] Bellmann, L., Kohaut, S. and M. Lahner (2002), Das IAB-Betriebspanel Ansatz und Analysepotenziale, in: Kleinhenz, G. (ed.), IAB-Kompendium Arbeitsmarkt- und Berufsforschung, Beiträge zur Arbeitsmarkt- und Berufsforschung 250, 13-20. Nürnberg.

[8] Blanchflower, D.G., Oswald, A.J. and P. Sanfey (1996), Wages, profits, and rent-sharing, Quarterly Journal of Economics 111, 227-251.

[9] Bond, S.R. (2002), Dynamic panel data models: A guide to micro data methods and practice, Portuguese Economic Journal 1, 141-162.

[10] Calmfors, L. and J. Driffill (1988), Centralization of wage bargaining, Economic Policy 6, 12-61.

[11] Cardoso, A. R. and P. Portugal (2003), Bargained wages, wage drift and the design of the wage-setting system, IZA Discussion Paper No. 914, Bonn.

[12] Christofides, L. and A. Oswald (1992), Real wage determination and rent-sharing in collective bargaining agreements, Quarterly Journal of Economics 107, 9851002 .

[13] Corneo, G. (1995), National wage bargaining in an internationally integrated product market, European Journal of Political Economy 11, 503-520.

[14] Dobbelaere, S. (2004), Ownership, firm-size and rent-sharing in Bulgaria, Labour Economics 11, 165-189. 
[15] Dowrick, S. (1993), Enterprise bargaining, union structure and wages, The Economic Record 69, 393-404.

[16] Fitzenberger, B. and W. Franz (1999), Industry-level wage bargaining: A partial rehabilitation - the German experience, Scottish Journal of Political Economy 46, 437-456.

[17] Franz, W. and F. Pfeiffer (2003), Zur ökonomischen Rationalität von Lohnrigiditäten aus der Sicht von Unternehmen, Jahrbücher für Nationalökonomie und Statistik 223, 23-57.

[18] Gerlach, K. and O. Hübler (1998), Firm size and wages in Germany - trends and impact of mobility, Empirica 25, 245-261.

[19] Hartog, J., Leuven, E. and C. Teulings (2002), Wages and the bargaining regime in a corporatist setting: the Netherlands, European Journal of Political Economy $18,317-331$.

[20] Hassel, A. (1999), The erosion of the German system of Industrial Relations, British Journal of Industrial Relations 37, 483-506.

[21] Haucap, J. and C. Wey (2004), Unionisation structures and innovation incentives, The Economic Journal 114, C149-C165.

[22] Hempell, T. (2002), What's spurious? What's real? Measuring the productivity impacts of ICT at the firm level, ZEW Discussion Paper 02-42. Mannheim.

[23] Hildreth, A. and A.J. Oswald (1997), Rent-sharing and wages: evidence from company and establishment panels, Journal of Labor Economics 15, 318-337.

[24] Holmlund, B. and J. Zetterberg. (1991), Insider effects in wage determination: evidence from five countries, European Economic Review 35, 1009-1034.

[25] Hübler, O. and A. König (1998), Produktmarkteinflüsse, Renten und Löhne: Eine semiparametrische Untersuchung, in: Gerlach, K. (ed.): Ökonomische Analysen betrieblicher Strukturen und Entwicklungen: das Hannoveraner Firmenpanel, 119-143. Frankfurt.

[26] Hübler, O. and U. Jirjahn (2003), Works councils and collective bargaining in Germany: The impact on productivity and wages, Scottish Journal of Political Economy 51, 471-492.

[27] Klodt, T. (2000), Produktmärkte, Rent-Sharing und Lohnhöhe. Frankfurt a.M.

[28] Kohaut, S. and C. Schnabel (2003), Zur Erosion des Fächentarifvertrags: Ausmaß, Einflussfaktoren und Gegenmaßnahmen, Industrielle Beziehungen 10, 193219 .

[29] Margolis, D.N. and K.G. Salvanes (2001), Do firms really share rents with their workers?, IZA Discussion Paper 330. Bonn. 
[30] Ochel, W. (2003), Decentralising wage bargaining in Germany - a way to increase employment?, CESIFO Working Paper No. 1069. München.

[31] OECD (2004), Employment Outlook, Paris.

[32] Oi, W.Y. and T.L. Idson (1999), Firm size and wages, in: Ashenfelter, O. and D. Card, Handbook of Labor Economics. Vol. 3, Amsterdam.

[33] van Reenen, J. (1996), The creation and capture of rents: wages and innovation in a panel of U.K. companies, Quarterly Journal of Economics 111, 195-226.

[34] Schmidt, C.M. and K.F. Zimmermann (1991), Work characteristics, firm size and wages, Review of Economics and Statistics 73, 705-710.

[35] Soskice, D. (1990), Wage determination: The changing role of institutions in advanced industrialized countries, Oxford Review of Economic Policy 6, 36-61. 


\section{A Appendix}

\section{A.1 Proposition 1:}

Regime $(D)$ : With $U_{i}=\left(w_{i}-\bar{w}\right) l_{i}=\left(w_{i}-\bar{w}\right) c_{i} q_{i}, i=1, \ldots, n$, the first-order condition for each union $i$ is

$$
\frac{\partial U_{i}}{\partial w_{i}}=l_{i}+\frac{\partial l_{i}}{\partial w_{i}}\left(w_{i}-\bar{w}\right)=c_{i} \frac{a-n w_{i} c_{i}+\sum_{j \neq i} w_{j} c_{j}}{b(n+1)}-n c_{i}^{2} \frac{\left(w_{i}-\bar{w}\right)}{b(n+1)}=0
$$

yielding $n$ reaction functions

$$
w_{i}=\frac{a+n c_{i} \bar{w}+\sum_{j \neq i} w_{j} c_{j}}{2 n c_{i}}, i=1, \ldots, n
$$

Regime $(I)$ : With $U^{I}=\sum_{j=1}^{n}\left(w_{j}-\bar{w}\right) l_{j}=\sum_{j=1}^{n}\left(w_{j}-\bar{w}\right) c_{j} q_{j}$, the first-order condition for each wage $w_{i}$ is

$$
\begin{gathered}
\frac{\partial U}{\partial w_{i}}=\frac{\partial \sum_{j=1}^{n} U_{j}}{\partial w_{i}}=\left(l_{i}+\frac{\partial l_{i}}{\partial w_{i}}\left(w_{i}-\bar{w}\right)+\sum_{j \neq i} \frac{\partial U_{j}}{\partial w_{i}}\right)=0 \\
\Leftrightarrow c_{i} \frac{a-n w_{i} c_{i}+\sum_{j \neq i} w_{j} c_{j}}{b(n+1)}-n c_{i}^{2} \frac{\left(w_{i}-\bar{w}\right)}{b(n+1)}+\sum_{j \neq i} c_{i} c_{j} \frac{\left(w_{j}-\bar{w}\right)}{b(n+1)}=0,
\end{gathered}
$$

yielding $n$ reaction functions

$$
w_{i}=\frac{a+n c_{i} \bar{w}+2 \sum_{j \neq i} w_{j} c_{j}-\bar{w} \sum_{j \neq i} c_{j}}{2 n c_{i}}, i=1, \ldots, n .
$$

Regime $(C)$ : With $U^{C}=\sum_{j=1}^{n}(w-\bar{w}) l_{j}=\sum_{j=1}^{n}(w-\bar{w}) c_{j} q_{j}$, the first-order condition for the uniform industry-wage $w$ is

$$
\begin{gathered}
\frac{\partial U}{\partial w}=\frac{\partial \sum_{j=1}^{n} U_{j}}{\partial w}=\left(\sum_{j=1}^{n}\left(l_{j}+(w-\bar{w}) \frac{\partial l_{j}}{\partial w}\right)=0\right. \\
\Leftrightarrow \sum_{j=1}^{n} c_{j} \frac{a-n w c_{j}+\sum_{i \neq j} w c_{i}}{b(n+1)}+\frac{c_{j}(w-\bar{w})}{b(n+1)}\left(-n c_{j}+\sum_{i \neq j} c_{i}\right)=0 .
\end{gathered}
$$

\section{A.2 Proposition 2:}

Regime $(D)$ :

$$
\begin{aligned}
& \lim _{n \rightarrow \infty} w_{i}^{D}=\lim _{n \rightarrow \infty} \frac{(2 n+1) a / c_{i}+n \bar{w}\left[(n+1)+n\left(\bar{c} / c_{i}\right)\right]}{(n+1)(2 n+1)} \\
\Rightarrow & \lim _{n \rightarrow \infty}\left[\frac{a / c_{i}}{(n+1)}+\frac{n \bar{w}}{(2 n+1)}+\frac{n^{2} \bar{w}}{\left(2 n^{2}+3 n+1\right)} \frac{\bar{c}}{c_{i}}\right]=\frac{\bar{w}}{2}+\frac{\overline{w c}}{2 c_{i}}
\end{aligned}
$$


Regime $(C)$ : To derive the limit of $w^{C}$, it is first necessary to show that $V A R(c)$ is bounded from above, if all firms in the industry are supposed to produce positive quantities of the homogeneous product. In particular, $q_{i}>0$ requires that the term $\left[a-\left((n+1)\left(c_{i}-\bar{c}\right)+\bar{c}\right) w^{C}\right]$ be positive for all $c_{i}$. (see eq. $\left.(3)\right)$.

This implies for positive $w^{C}$ and $c_{i}<\bar{c}$ that $\left|c_{i}-\bar{c}\right|<\bar{c} /(n+1)<a /(\bar{w}(n+1))$ and for $w^{C}>\bar{w}$ and $c_{i}>\bar{c}$ that $\left((n+1)\left(c_{i}-\bar{c}\right)+\bar{c}\right)<a / \bar{w}$. Together this yields that $\left|c_{i}-\bar{c}\right|<a /(\bar{w}(n+1))$ and $V A R(c)<[a /(\bar{w}(n+1))]^{2}$.

Therefore we have $0<(n+1) V A R(c)<a^{2} /\left(\bar{w}^{2}(n+1)\right):=\Psi$, so that

$$
\Phi:=\frac{\bar{w}}{2}+\frac{a \bar{c}}{2\left(\Psi+\bar{c}^{2}\right)}<w^{C}<\frac{\bar{w}}{2}+\frac{a}{2 \bar{c}} .
$$

Since $\lim _{n \rightarrow \infty} \Psi=0, \lim _{n \rightarrow \infty} \Phi=\frac{\bar{w}}{2}+\frac{a}{2 \bar{c}}$, which proves part (iii) of Proposition 2 .

\section{A.3 Proposition 3 :}

(ii) The difference between the derivatives $d w_{i}^{I} / d c_{i}$ and $d w_{i}^{D} / d c_{i}$ is given by:

$$
\frac{d w_{i}^{I}}{d c_{i}}-\frac{d w_{i}^{D}}{d c_{i}}=\frac{a\left(2 n^{2}-n-1\right)-2 n^{2} \bar{w} \bar{c}}{2 c_{i}^{2}(2 n+1)(n+1)} .
$$

(iii) With $R_{i} / l_{i}=\left(P q_{i}-\bar{w} l_{i}\right) / l_{i}=P / c_{i}-\bar{w}$ denoting per-capita quasi-rents in firm $i$, it follows $d R_{i} / d c_{i}=-P / c_{i}^{2}$. With eq. (35) we obtain:

$$
\frac{d w_{i}^{I}}{d R_{i}^{I}}-\frac{d w_{i}^{D}}{d R_{i}^{D}}=\frac{a\left(2 n^{2}-n-1\right)-2 n^{2} \bar{w} \bar{c}}{2 P(n+1)(2 n+1)} .
$$




\section{A.4 Descriptive Statistics by Bargaining Coverage:}

\begin{tabular}{lrrrrrr} 
& \multicolumn{2}{c}{ CENT } & \multicolumn{2}{c}{ DECENT } & \multicolumn{2}{c}{ NO COVERAGE } \\
\cline { 2 - 7 } Variables & Mean & Std.-Dev. & Mean & Std.-Dev. & Mean & \multicolumn{1}{c}{ Std.-Dev. } \\
\hline \hline$w$ & 54.64 & 17.66 & 48.37 & 16.04 & 38.78 & 17.95 \\
$\pi$ & 84.25 & 102.53 & 66.71 & 90.43 & 34.97 & 64.49 \\
$\bar{w}$ & 54.30 & 10.83 & 51.33 & 11.26 & 48.79 & 12.50 \\
HIGHSHARE & 0.27 & 0.20 & 0.26 & 0.20 & 0.19 & 0.19 \\
BLUESHARE & 0.39 & 0.22 & 0.47 & 0.23 & 0.48 & 0.25 \\
APPSHARE & 0.04 & 0.06 & 0.04 & 0.05 & 0.05 & 0.07 \\
FEMSHARE & 0.26 & 0.19 & 0.24 & 0.19 & 0.29 & 0.24 \\
SIZE & 865.33 & 3123.63 & 417.65 & 870.11 & 75.81 & 161.27 \\
WCOUNCIL & 0.80 & 0.40 & 0.75 & 0.44 & 0.24 & 0.43 \\
K/L & 204.85 & 400.02 & 721.65 & 3780.18 & 150.59 & 385.72 \\
EAST & 0.23 & 0.42 & 0.45 & 0.50 & 0.54 & 0.50 \\
OWN & 0.20 & 0.40 & 0.12 & 0.32 & 0.28 & 0.45 \\
\hline Obs. & \multicolumn{5}{c}{392} \\
\hline \hline
\end{tabular}

Source: IAB-Establishment Panel 1995-2002. Data processing through the Research Data Centre (FDZ) of the Federal Employment Services (BA) at the Institute of Employment Research, Nuremberg.

Note: All monetary values are measured in 1000 DM. $1 \notin$ corresponds to 1.95583 DM.

Table A1: Descriptive Statistics by Bargaining Coverage 


\section{A.5 Dynamic Panel Data Regression Results}

\begin{tabular}{|c|c|c|c|c|}
\hline Model & 1 & 2 & 3 & 4 \\
\hline $\bar{w}$ & $\begin{array}{l}0.086^{*} \\
(0.047)\end{array}$ & $\begin{array}{l}0.062 \\
(0.049)\end{array}$ & $\begin{array}{l}0.050 \\
(0.050)\end{array}$ & $\begin{array}{l}0.083 \\
(0.056)\end{array}$ \\
\hline$w(\mathrm{t}-1)$ & & $\begin{array}{l}0.059 \\
(0.042)\end{array}$ & $\begin{array}{l}0.061 \\
(0.043)\end{array}$ & $\begin{array}{l}-0.009 \\
(0.056)\end{array}$ \\
\hline$\pi$ & $\begin{array}{l}0.078^{* * *} \\
(0.028)\end{array}$ & $\begin{array}{l}0.060^{* *} \\
(0.025)\end{array}$ & $\begin{array}{l}0.052^{* *} \\
(0.024)\end{array}$ & $\begin{array}{l}0.043 \\
(0.028)\end{array}$ \\
\hline$\pi * \mathrm{CENT}$ & $\begin{array}{l}-0.082^{* *} \\
(0.032)\end{array}$ & $\begin{array}{l}-0.071^{* *} \\
(0.029)\end{array}$ & $\begin{array}{l}-0.072^{* * *} \\
(0.027)\end{array}$ & $\begin{array}{l}-0.062^{* *} \\
(0.029)\end{array}$ \\
\hline$\pi * \mathrm{DECENT}$ & $\begin{array}{l}-0.097^{* *} \\
(0.041)\end{array}$ & $\begin{array}{l}-0.085^{* *} \\
(0.041)\end{array}$ & $\begin{array}{l}-0.082^{* *} \\
(0.040)\end{array}$ & $\begin{array}{l}-0.066^{*} \\
(0.037)\end{array}$ \\
\hline$\pi(\mathrm{t}-1)$ & & & $\begin{array}{l}0.024 \\
(0.024)\end{array}$ & $\begin{array}{l}0.034 \\
(0.033)\end{array}$ \\
\hline$\pi * \mathrm{CENT}(\mathrm{t}-1)$ & & & $\begin{array}{l}-0.012 \\
(0.021)\end{array}$ & $\begin{array}{l}-0.027 \\
(0.027)\end{array}$ \\
\hline$\pi * \operatorname{DECENT}(\mathrm{t}-1)$ & & & $\begin{array}{l}-0.015 \\
(0.022)\end{array}$ & $\begin{array}{l}-0.014 \\
(0.035)\end{array}$ \\
\hline$\pi(\mathrm{t}-2)$ & & & & $\begin{array}{l}0.044^{*} \\
(0.024)\end{array}$ \\
\hline$\pi * \mathrm{CENT}(\mathrm{t}-2)$ & & & & $\begin{array}{l}-0.047^{*} \\
(0.024)\end{array}$ \\
\hline$\pi * \operatorname{DECENT}(\mathrm{t}-2)$ & & & & $\begin{array}{l}-0.035 \\
(0.028)\end{array}$ \\
\hline $\begin{array}{l}\pi=-\pi * \mathrm{CENT} \\
(p-\text { value })\end{array}$ & 0.776 & 0.460 & 0.221 & 0.306 \\
\hline $\begin{array}{l}\pi=-\pi * D E C E N T \\
(p-\text { value })\end{array}$ & 0.491 & 0.400 & 0.322 & 0.357 \\
\hline
\end{tabular}

${ }^{*}$ Significant at 10\%-level.

** Significant at 5\%-level.

*** Significant at $1 \%$-level.

Table A2: Differenced GMM regression results ... to be continued on next page 
... continue Table A2

\begin{tabular}{|c|c|c|c|c|}
\hline Model & 1 & 2 & 3 & 4 \\
\hline HIGHSHARE & $\begin{array}{l}-8.763^{*} \\
(4.539)\end{array}$ & $\begin{array}{l}-4.987 \\
(4.789)\end{array}$ & $\begin{array}{l}-4.567 \\
(4.610)\end{array}$ & $\begin{array}{l}-8.346 \\
(6.457)\end{array}$ \\
\hline BLUESHARE & $\begin{array}{l}-1.808 \\
(2.526)\end{array}$ & $\begin{array}{l}1.465 \\
(3.099)\end{array}$ & $\begin{array}{l}1.450 \\
(3.027)\end{array}$ & $\begin{array}{l}4.706 \\
(3.592)\end{array}$ \\
\hline APPSHARE & $\begin{array}{l}-16.782^{* *} \\
(8.184)\end{array}$ & $\begin{array}{l}-5.858 \\
(10.255)\end{array}$ & $\begin{array}{l}-6.273 \\
(10.021)\end{array}$ & $\begin{array}{l}-1.611 \\
(13.413)\end{array}$ \\
\hline FEMSHARE & $\begin{array}{l}-2.660 \\
(8.723)\end{array}$ & $\begin{array}{l}-6.002 \\
(9.236)\end{array}$ & $\begin{array}{l}-5.918 \\
(9.096)\end{array}$ & $\begin{array}{l}-5.617 \\
(10.717)\end{array}$ \\
\hline SIZE & $\begin{array}{l}-0.002 \\
(0.003)\end{array}$ & $\begin{array}{l}-0.001 \\
(0.003)\end{array}$ & $\begin{array}{l}0.0003 \\
(0.003)\end{array}$ & $\begin{array}{l}0.002 \\
(0.004)\end{array}$ \\
\hline $\mathrm{SIZE}^{2}$ & $\begin{array}{l}-2.63 e^{-08} \\
\left(3.12 e^{-08}\right)\end{array}$ & $\begin{array}{l}-2.27 e^{-08} \\
\left(3.08 e^{-08}\right)\end{array}$ & $\begin{array}{l}-1.21 e^{-08} \\
\left(3.33 e^{-08}\right)\end{array}$ & $\begin{array}{l}-8.89 e^{-09} \\
\left(4.64 e^{-08}\right)\end{array}$ \\
\hline CENT & $\begin{array}{l}3.344^{* *} \\
(1.702)\end{array}$ & $\begin{array}{l}3.141^{*} \\
(1.636)\end{array}$ & $\begin{array}{l}3.323^{* *} \\
(1.582)\end{array}$ & $\begin{array}{l}2.897^{*} \\
(1.592)\end{array}$ \\
\hline DECENT & $\begin{array}{l}4.113^{* *} \\
(1.937)\end{array}$ & $\begin{array}{l}3.704^{*} \\
(1.985)\end{array}$ & $\begin{array}{l}3.504^{*} \\
(1.960)\end{array}$ & $\begin{array}{l}2.748 \\
(1.929)\end{array}$ \\
\hline WCOUNCIL & $\begin{array}{l}-2.218 \\
(2.063)\end{array}$ & $\begin{array}{l}-2.636 \\
(2.112)\end{array}$ & $\begin{array}{l}-2.904 \\
(2.097)\end{array}$ & $\begin{array}{l}-1.627 \\
(2.602)\end{array}$ \\
\hline $\mathrm{K} / \mathrm{L}$ & $\begin{array}{l}-0.001^{* * *} \\
(0.0004)\end{array}$ & $\begin{array}{l}-0.002^{* * *} \\
(0.0003)\end{array}$ & $\begin{array}{l}-0.002^{* * *} \\
(0.0003)\end{array}$ & $\begin{array}{l}-0.002^{* * *} \\
(0.0003)\end{array}$ \\
\hline $\begin{array}{l}\text { Sargan/Hansen } \\
\text { ( } p \text {-value) }\end{array}$ & 0.352 & 0.485 & 0.616 & 0.362 \\
\hline $\operatorname{AR}(2)(p-$ value $)$ & 0.982 & 0.490 & 0.710 & 0.436 \\
\hline Firms & 661 & 661 & 661 & 661 \\
\hline Observations & 2750 & 2089 & 2089 & 1428 \\
\hline
\end{tabular}

Note: The dependent variable is the aggregate per-capita wagebill. All variables are first-differenced. Results are reported for one-step differenced GMM-estimators. All specifications include time dummies.

Heteroscedasticity-robust standard-errors are in parentheses.

* Significant at $10 \%$-level.

** Significant at 5\%-level.

*** Significant at $1 \%$-level.

Table A2: Differenced GMM regression results 


\begin{tabular}{|c|c|c|c|c|}
\hline Model & 1 & 2 & 3 & 4 \\
\hline$\overline{\bar{w}}$ & $\begin{array}{l}0.280^{* *} \\
(0.132)\end{array}$ & $\begin{array}{l}0.120 \\
(0.133)\end{array}$ & $\begin{array}{l}0.081 \\
(0.144)\end{array}$ & $\begin{array}{l}0.170 \\
(0.170)\end{array}$ \\
\hline$w(\mathrm{t}-1)$ & & $\begin{array}{l}0.281^{* * *} \\
(0.043)\end{array}$ & $\begin{array}{l}0.285^{* * *} \\
(0.043)\end{array}$ & $\begin{array}{l}0.283^{* * *} \\
(0.047)\end{array}$ \\
\hline$\pi$ & $\begin{array}{l}0.111^{* * *} \\
(0.030)\end{array}$ & $\begin{array}{l}0.089^{* * *} \\
(0.030)\end{array}$ & $\begin{array}{l}0.077^{* *} \\
(0.030)\end{array}$ & $\begin{array}{l}0.071^{* *} \\
(0.030)\end{array}$ \\
\hline$\pi * \mathrm{CENT}$ & $\begin{array}{l}-0.086^{* *} \\
(0.035)\end{array}$ & $\begin{array}{l}-0.072^{* *} \\
(0.036)\end{array}$ & $\begin{array}{l}-0.080^{* * *} \\
(0.031)\end{array}$ & $\begin{array}{l}-0.067^{* *} \\
(0.031)\end{array}$ \\
\hline$\pi * \mathrm{DECENT}$ & $\begin{array}{l}-0.073^{*} \\
(0.044)\end{array}$ & $\begin{array}{l}-0.075^{* *} \\
(0.037)\end{array}$ & $\begin{array}{l}-0.071^{* *} \\
(0.033)\end{array}$ & $\begin{array}{l}-0.073^{* *} \\
(0.035)\end{array}$ \\
\hline$\pi(\mathrm{t}-1)$ & & & $\begin{array}{l}0.001 \\
(0.017)\end{array}$ & $\begin{array}{l}-0.007 \\
(0.020)\end{array}$ \\
\hline$\pi * \mathrm{CENT}(\mathrm{t}-1)$ & & & $\begin{array}{l}0.025 \\
(0.014)\end{array}$ & $\begin{array}{l}0.033 \\
(0.016)\end{array}$ \\
\hline$\pi * \operatorname{DECENT}(\mathrm{t}-1)$ & & & $\begin{array}{l}0.011 \\
(0.017)\end{array}$ & $\begin{array}{l}0.037 \\
(0.019)\end{array}$ \\
\hline$\pi(\mathrm{t}-2)$ & & & & $\begin{array}{l}0.007 \\
(0.015)\end{array}$ \\
\hline$\pi * \mathrm{CENT}(\mathrm{t}-2)$ & & & & $\begin{array}{l}-0.006 \\
(0.017)\end{array}$ \\
\hline$\pi * \operatorname{DECENT}(\mathrm{t}-2)$ & & & & $\begin{array}{l}0.008 \\
(0.020)\end{array}$ \\
\hline $\begin{array}{l}\pi=-\pi * \text { CENT } \\
(p-\text { value })\end{array}$ & 0.093 & 0.223 & 0.825 & 0.759 \\
\hline $\begin{array}{l}\pi=-\pi * D E \mathrm{CENT} \\
(p-\text { value })\end{array}$ & 0.146 & 0.401 & 0.766 & 0.920 \\
\hline
\end{tabular}

Table A3: SYS-GMM regression results ... to be continued on next page 
... continue Table A3

\begin{tabular}{|c|c|c|c|c|}
\hline Model & 1 & 2 & 3 & 4 \\
\hline HIGHSHARE & $\begin{array}{l}-10.044^{*} \\
(5.242)\end{array}$ & $\begin{array}{l}-5.325 \\
(5.371)\end{array}$ & $\begin{array}{l}-4.135 \\
(5.205)\end{array}$ & $\begin{array}{l}-0.776 \\
(6.061)\end{array}$ \\
\hline BLUESHARE & $\begin{array}{l}-3.074 \\
(3.204)\end{array}$ & $\begin{array}{l}-0.178 \\
(3.320)\end{array}$ & $\begin{array}{l}0.205 \\
(3.287)\end{array}$ & $\begin{array}{l}4.312 \\
(4.150)\end{array}$ \\
\hline APPSHARE & $\begin{array}{l}-22.432^{* *} \\
(11.187)\end{array}$ & $\begin{array}{l}-23.407^{*} \\
(12.263)\end{array}$ & $\begin{array}{l}-22.606^{*} \\
(12.399)\end{array}$ & $\begin{array}{l}-4.152 \\
(17.404)\end{array}$ \\
\hline FEMSHARE & $\begin{array}{l}-6.927 \\
(5.456)\end{array}$ & $\begin{array}{l}-8.021 \\
(4.931)\end{array}$ & $\begin{array}{l}-6.923 \\
(4.892)\end{array}$ & $\begin{array}{l}-7.962 \\
(5.334)\end{array}$ \\
\hline SIZE & $\begin{array}{l}0.003^{* * *} \\
(0.0008)\end{array}$ & $\begin{array}{l}0.002^{* * *} \\
(0.0007)\end{array}$ & $\begin{array}{l}0.002^{* * *} \\
(0.0007)\end{array}$ & $\begin{array}{l}0.002^{* * *} \\
(0.0008)\end{array}$ \\
\hline SIZE $^{2}$ & $\begin{array}{l}-4.76 e^{-08 * * *} \\
\left(1.74 e^{-08}\right)\end{array}$ & $\begin{array}{l}-2.93 e^{-08 *} \\
1.61 e^{-08}\end{array}$ & $\begin{array}{l}-2.89 e^{-08 *} \\
\left(1.66 e^{-08}\right)\end{array}$ & $\begin{array}{l}-3.64 e^{-08 * *} \\
\left(1.72 e^{-08}\right)\end{array}$ \\
\hline CENT & $\begin{array}{l}7.599^{* * *} \\
(2.013)\end{array}$ & $\begin{array}{l}6.457^{* * *} \\
(1.932)\end{array}$ & $\begin{array}{l}6.959^{* * *} \\
(1.855)\end{array}$ & $\begin{array}{l}6.085^{* * *} \\
(2.050)\end{array}$ \\
\hline DECENT & $\begin{array}{l}3.731^{*} \\
(2.131)\end{array}$ & $\begin{array}{l}4.270^{* *} \\
(1.860)\end{array}$ & $\begin{array}{l}4.095^{* *} \\
(1.851)\end{array}$ & $\begin{array}{l}4.610^{*} \\
(2.442)\end{array}$ \\
\hline WCOUNCIL & $\begin{array}{l}9.244^{* * *} \\
(2.893)\end{array}$ & $\begin{array}{l}5.643^{* *} \\
(2.498)\end{array}$ & $\begin{array}{l}5.428^{* *} \\
(2.495)\end{array}$ & $\begin{array}{l}6.742^{* *} \\
(2.659)\end{array}$ \\
\hline $\mathrm{K} / \mathrm{L}$ & $\begin{array}{l}0.0004^{* *} \\
(0.0002)\end{array}$ & $\begin{array}{l}0.0001 \\
(0.0001)\end{array}$ & $\begin{array}{l}0.0001 \\
(0.0002)\end{array}$ & $\begin{array}{l}0.0002 \\
(0.0002)\end{array}$ \\
\hline $\begin{array}{l}\text { Sargan/Hansen } \\
(p \text {-value })\end{array}$ & 0.115 & 0.166 & 0.205 & 0.256 \\
\hline $\begin{array}{l}\text { Diff. Test comp. to } \\
\text { Table A2 ( } p \text {-value) }\end{array}$ & 0.031 & 0.022 & 0.012 & 0.192 \\
\hline $\operatorname{AR}(2)(p$-value $)$ & 0.872 & 0.069 & 0.133 & 0.106 \\
\hline Firms & 661 & 661 & 661 & 661 \\
\hline Observations & 2750 & 2750 & 2750 & 2089 \\
\hline
\end{tabular}

Note: The dependent variable is the aggregate per-capita wagebill. Results are reported for one-step SYS-GMM-estimators. All specifications include industry and time dummies as well as an east-west and an ownership dummy.

Heteroscedasticity-robust standard-errors are in parentheses.

*Significant at $10 \%$-level.

** Significant at 5\%-level.

${ }^{* * *}$ Significant at $1 \%$-level.

Table A3: SYS-GMM regression results 


\begin{tabular}{|c|c|c|c|c|}
\hline Model & 1 & 2 & 3 & 4 \\
\hline$\overline{\bar{w}}$ & $\begin{array}{l}0.433^{* * *} \\
(0.136)\end{array}$ & $\begin{array}{l}0.204^{*} \\
(0.121)\end{array}$ & $\begin{array}{l}0.170 \\
(0.135)\end{array}$ & $\begin{array}{l}0.242 \\
(0.155)\end{array}$ \\
\hline$w(\mathrm{t}-1)$ & & $\begin{array}{l}0.326^{* * *} \\
(0.043)\end{array}$ & $\begin{array}{l}0.328^{* * *} \\
(0.043)\end{array}$ & $\begin{array}{l}0.304^{* * *} \\
(0.048)\end{array}$ \\
\hline$\pi$ & $\begin{array}{l}0.108^{* * *} \\
(0.030)\end{array}$ & $\begin{array}{l}0.081^{* * *} \\
(0.026)\end{array}$ & $\begin{array}{l}0.074^{* * *} \\
(0.026)\end{array}$ & $\begin{array}{l}0.071^{* *} \\
(0.028)\end{array}$ \\
\hline$\pi * \mathrm{CENT}$ & $\begin{array}{l}-0.075^{* *} \\
(0.034)\end{array}$ & $\begin{array}{l}-0.067^{* *} \\
(0.031)\end{array}$ & $\begin{array}{l}-0.078^{* * *} \\
(0.027)\end{array}$ & $\begin{array}{l}-0.060^{*} \\
(0.031)\end{array}$ \\
\hline$\pi * \mathrm{DECENT}$ & $\begin{array}{l}-0.075^{*} \\
(0.042)\end{array}$ & $\begin{array}{l}-0.070^{* *} \\
(0.032)\end{array}$ & $\begin{array}{l}-0.067^{* *} \\
(0.029)\end{array}$ & $\begin{array}{l}-0.069^{* *} \\
(0.034)\end{array}$ \\
\hline$\pi(\mathrm{t}-1)$ & & & $\begin{array}{l}-0.005 \\
(0.017)\end{array}$ & $\begin{array}{l}-0.008 \\
(0.020)\end{array}$ \\
\hline$\pi * \mathrm{CENT}(\mathrm{t}-1)$ & & & $\begin{array}{l}0.030^{* *} \\
(0.013)\end{array}$ & $\begin{array}{l}0.036^{* *} \\
(0.016)\end{array}$ \\
\hline$\pi * \operatorname{DECENT}(\mathrm{t}-1)$ & & & $\begin{array}{l}0.011 \\
(0.016)\end{array}$ & $\begin{array}{l}0.028 \\
(0.020)\end{array}$ \\
\hline$\pi(\mathrm{t}-2)$ & & & & $\begin{array}{l}0.005 \\
(0.014)\end{array}$ \\
\hline$\pi * \mathrm{CENT}(\mathrm{t}-2)$ & & & & $\begin{array}{l}-0.004 \\
(0.016)\end{array}$ \\
\hline$\pi * \operatorname{DECENT}(\mathrm{t}-2)$ & & & & $\begin{array}{l}0.004 \\
(0.019)\end{array}$ \\
\hline $\begin{array}{l}\pi=-\pi * \mathrm{CENT} \\
(p-\text { value })\end{array}$ & 0.037 & 0.289 & 0.727 & 0.452 \\
\hline $\begin{array}{l}\pi=-\pi * D E C E N T \\
(p-\text { value })\end{array}$ & 0.176 & 0.479 & 0.740 & 0.921 \\
\hline
\end{tabular}

${ }^{*}$ Significant at $10 \%$-level.

** Significant at 5\%-level.

${ }^{* * *}$ Significant at $1 \%$-level.

Table A4: SYS-GMM regression results

... to be continued on next page 
... continue Table A4

\begin{tabular}{|c|c|c|c|c|}
\hline Model & 1 & 2 & 3 & 4 \\
\hline HIGHSHARE & $\begin{array}{l}-4.588 \\
(5.137)\end{array}$ & $\begin{array}{l}2.553 \\
(4.260)\end{array}$ & $\begin{array}{l}3.660 \\
(4.199)\end{array}$ & $\begin{array}{l}5.170 \\
(5.033)\end{array}$ \\
\hline BLUESHARE & $\begin{array}{l}-3.661 \\
(2.552)\end{array}$ & $\begin{array}{l}0.416 \\
(1.964)\end{array}$ & $\begin{array}{l}0.920 \\
(1.989)\end{array}$ & $\begin{array}{l}3.215 \\
(2.563)\end{array}$ \\
\hline APPSHARE & $\begin{array}{l}-1.646 \\
(11.475)\end{array}$ & $\begin{array}{l}-5.661 \\
(10.461)\end{array}$ & $\begin{array}{l}-7.045 \\
(11.186)\end{array}$ & $\begin{array}{l}-5.706 \\
(13.366)\end{array}$ \\
\hline FEMSHARE & $\begin{array}{l}-10.844^{* *} \\
(4.920)\end{array}$ & $\begin{array}{l}-11.419^{* * *} \\
(3.553)\end{array}$ & $\begin{array}{l}-9.827^{* * *} \\
(3.555)\end{array}$ & $\begin{array}{l}-8.367^{*} \\
(4.560)\end{array}$ \\
\hline SIZE & $\begin{array}{l}0.002^{* * *} \\
(0.0007)\end{array}$ & $\begin{array}{l}0.002^{* * *} \\
(0.0005)\end{array}$ & $\begin{array}{l}0.002^{* * *} \\
(0.0005)\end{array}$ & $\begin{array}{l}0.003^{* * *} \\
(0.0006)\end{array}$ \\
\hline $\mathrm{SIZE}^{2}$ & $\begin{array}{l}-3.54 e^{-08 * *} \\
\left(1.46 e^{-08}\right)\end{array}$ & $\begin{array}{l}-2.16 e^{-08 *} \\
\left(1.21 e^{-08}\right)\end{array}$ & $\begin{array}{l}-2.17 e^{-08 *} \\
\left(1.26 e^{-08}\right)\end{array}$ & $\begin{array}{l}-4.31 e^{-08 * * *} \\
\left(1.45 e^{-08}\right)\end{array}$ \\
\hline CENT & $\begin{array}{l}7.066^{* * *} \\
(1.947)\end{array}$ & $\begin{array}{l}6.666^{* * *} \\
(1.771)\end{array}$ & $\begin{array}{l}7.208^{* * *} \\
(1.713)\end{array}$ & $\begin{array}{l}5.782^{* * *} \\
(2.069)\end{array}$ \\
\hline DECENT & $\begin{array}{l}4.087^{*} \\
(2.101)\end{array}$ & $\begin{array}{l}4.539^{* * *} \\
(1.705)\end{array}$ & $\begin{array}{l}4.338^{* *} \\
(1.777)\end{array}$ & $\begin{array}{l}4.360^{*} \\
(2.403)\end{array}$ \\
\hline WCOUNCIL & $\begin{array}{l}12.365^{* * *} \\
(3.034)\end{array}$ & $\begin{array}{l}7.882^{* * *} \\
(2.346)\end{array}$ & $\begin{array}{l}7.622^{* * *} \\
(2.359)\end{array}$ & $\begin{array}{l}7.508^{* * *} \\
(2.611)\end{array}$ \\
\hline $\mathrm{K} / \mathrm{L}$ & $\begin{array}{l}0.0004^{* * *} \\
(0.0002)\end{array}$ & $\begin{array}{l}0.0001 \\
(0.0001)\end{array}$ & $\begin{array}{l}0.0002 \\
(0.0001) \\
\end{array}$ & $\begin{array}{l}0.0003^{*} \\
(0.0002) \\
\end{array}$ \\
\hline $\begin{array}{l}\text { Sargan/Hansen } \\
\text { ( } p \text {-value) }\end{array}$ & 0.184 & 0.284 & 0.252 & 0.463 \\
\hline $\begin{array}{l}\text { Diff. Test comp. to } \\
\text { Table A2 ( } p \text {-value) }\end{array}$ & 0.111 & 0.120 & 0.029 & 0.683 \\
\hline $\operatorname{AR}(2)(p$-value $)$ & 0.879 & 0.061 & 0.120 & 0.148 \\
\hline Firms & 661 & 661 & 661 & 661 \\
\hline Observations & 2750 & 2750 & 2750 & 2089 \\
\hline
\end{tabular}

Note: The dependent variable is the aggregate per-capita wagebill. Results are reported for one-step SYS-GMM-estimators. All specifications include industry and time dummies as well as an east-west and an ownership dummy.

Heteroscedasticity-robust standard-errors are in parentheses.

*Significant at $10 \%$-level.

** Significant at 5\%-level.

${ }^{* * *}$ Significant at $1 \%$-level.

Table A4: SYS-GMM regression results 